\title{
Monitoring or payroll maximization? What happens when workers enter the boardroom?
}

\author{
Cristi A. Gleason ${ }^{1}$ (D) $\cdot$ Sascha Kieback ${ }^{2} \cdot$ Martin Thomsen $^{2}$ (D) Christoph Watrin $^{2}$
}

Accepted: 25 May 2021/Published online: 25 August 2021

(C) The Author(s) 2021

\begin{abstract}
We examine whether worker representation on corporate boards results in improved monitoring or payroll maximization. Several economic theories predict that worker representatives would use control and voting rights in the boardroom to transform firm assets into private benefits and increased wages, but labor contract models suggest that workers' inside information should permit improved monitoring. To investigate this conflict, we use mandatory worker representation on corporate boards in Germany. Using hand-collected data, our results suggest that the worker representatives' payroll maximization incentives dominate their monitoring duties. Specifically, worker representatives reduce real earnings management when it results in wage cuts or job losses but not when it increases payroll or job security. Similarly, worker representatives are generally associated with improved monitoring of tax planning activities. However, when the risk of offshoring jobs is high, worker representatives do not promote tax planning for low-aggression firms and instead block aggressive tax planning for highaggression firms. This evidence helps policymakers and researchers better understand the role of workers in corporate governance systems and contributes to the ongoing public debate about introducing worker representation in the United States and the United Kingdom.
\end{abstract}

Keywords Worker representation · Monitoring · Payroll maximization · Agency conflict . Corporate governance $\cdot$ Earnings management $\cdot$ Tax avoidance

JEL classifications $\mathrm{G} 34 \cdot \mathrm{H} 25 \cdot \mathrm{K} 34 \cdot \mathrm{M} 41 \cdot \mathrm{M} 43$

Martin Thomsen

martin.thomsen@wiwi.uni-muenster.de

Extended author information available on the last page of the article 


\section{Introduction}

Worker representation on corporate boards is only recently receiving attention from politicians and the popular press in the United States and United Kingdom, although Germany mandated workers' participation at the end of the nineteenth century (e.g., McGaughey 2016; Bloomberg 2018a; Hockett et al. 2018; the Wall Street Journal 2018). In June 2019, the U.S. senator and Democratic presidential candidate Bernie Sanders attended Walmart's annual shareholder meeting, where he advocated for an employee-shareholder proposal to give workers a seat on the company's board (Budryk 2019). Sanders argued that "the concerns of workers, not just stockholders, should be a part of board decisions" (Krieg 2019). Shareholders voted down this proposal. Sanders' advocacy followed earlier proposals by another U.S. senator, Elizabeth Warren, and by Theresa May, the former British prime minister. ${ }^{1}$

We provide evidence on whether workers on corporate boards lead to improved monitoring of management that reduces agency costs, or prioritize payroll maximization at the cost of monitoring. This distinction is important because these two conflicting objectives are central to the debate surrounding the inclusion of workers on the board. ${ }^{2}$ Worker representation transfers some control and voting rights from shareholders to workers without requiring workers to have any equity ownership of the firm. Theoretical models imply that inclusion of workers on corporate boards could either improve board monitoring (Furubotn and Wiggins 1984; Freeman and Lazear 1995) or result in an opportunistic transformation of firm assets into increased wages and private benefits (Jensen and Meckling 1979; Furubotn 1988).

To date, studies of worker representation speak only to the net benefits or costs of worker representation, because the incentives to maximize payroll do not conflict with monitoring duties in these studies' settings. Studies generally find positive effects of worker representation on firm investments and profitability. However, it is difficult to infer, from these studies, the extent to which the workers' payroll maximization incentives impact firms' objective functions when workers are included on the board. We use the real earnings management and tax aggressiveness settings to answer this important question.

We examine specific transactions in the real earnings management and tax settings, where workers' incentives to maximize payroll are strongest and in direct conflict with their monitoring duties. These competing incentives provide us with advantages

\footnotetext{
${ }^{1}$ Senator Warren proposed that U.S. corporations "must ensure that no fewer than $40 \%$ of [their] directors are selected by the corporation's employees" as part of the Accountable Capitalism Act (Warren 2018). During her national campaign to become leader of the Conservative Party and prime minister, Theresa May said: "If I'm Prime Minister, . . . we're going to have not just consumers represented on company boards, but employees as well" (May 2016). Additionally, President Joe Biden emphasized that labor unions would have "increased power" in his administration (the New York Times 2020).

${ }^{2}$ For example, the political economist Susan R. Holmberg proposed that mandating worker representation on U.S. boards "could lead to better pay, benefits and job security" (the New York Times 2019). Similarly, Senator Warren argued that worker representation could reduce inequality between executive compensation and the average worker wage by shifting profits and benefits to workers (the Wall Street Journal 2018). In contrast, the business journalist Ursula Weidenfeld recommends that countries should beware of the negative consequences of, and should not adopt, German worker representation because it "has stifled innovation and hit profits" (Financial Times 2016), and Eric Morath argues that the economic payoff of worker representation would be uncertain (the Wall Street Journal 2019).
} 
relative to existing studies of worker representation, and allow us to directly address the debate, raised by politicians, unions and corporations, on the benefits and consequences of worker representation.

We study mandatory worker representation on corporate boards in publicly traded German companies. We use the German setting for several reasons. German worker representation serves as the role model in the discussion around whether to mandate worker representation in the United States (e.g., the New York Times 2019). ${ }^{3}$ The qualifications and training of worker representatives on the boards of German firms are well documented. Prior research finds robust evidence that workers on the boards of German firms impact the decision-making of corporate boards (FitzRoy and Kraft 1993; Gorton and Schmid 2004; Fauver and Fuerst 2006; Balsmeier et al. 2013; Lin et al. 2018; Petry 2018). Additionally, German and U.S. board systems for public firms are relatively comparable in terms of fiduciary responsibilities (e.g., Hopt 1997; Fauver and Fuerst 2006; Jungmann 2006; Linck et al. 2009; Balsmeier et al. 2013; Lin et al. 2018).

We hand-collect information on board composition, worker representation, governance quality, foreign activity (i.e., foreign sales, foreign subsidiaries, and foreign jobs), and the number of domestic workers from publicly available annual reports for the period 20092015. Financial statement data are provided by Compustat Global. Worker representation only applies to German firms with more than 500 domestic workers. Firms below this legal threshold are exempt from worker representation. This discontinuity allows us to analyze worker representation around a mandated threshold. We restrict the sample to firms with fewer than 1,000 domestic workers to compare observations on both sides of the threshold of 500 domestic workers. We confirm that firms with and without worker representation around this threshold are similar in firm size, which reduces concerns that our results are driven by a difference in this characteristic. Our real earnings management sample includes 978 firm-year observations, and our tax sample includes 670 firm-year observations. We estimate quantile regressions of real earnings management and tax aggressiveness on an indicator for worker representation and other firm control variables.

We predict that worker representatives will constrain real earnings management that threatens payroll. Conversely, we predict that worker representatives will not constrain real earnings management that increases payroll or job security. Prior research documents managers' use of overproduction and cuts to discretionary expenditures (such as selling and administrative expenses) to meet earnings objectives (e.g., Roychowdhury 2006; Cohen et al. 2008; Cohen and Zarowin 2010; Zang 2012). We predict that worker representation reduces the use of cuts to administrative expenditures to manage earnings, because those actions could lead to layoffs or wage reductions. Similarly, we expect that overproduction,

\footnotetext{
${ }^{3}$ Laws on "co-determination" are common in the majority of EU member states (18 out of 27). Germany requires firms with more than 500 domestic workers to assign at least one-third of the board seats to workers. While some countries have no such laws (e.g., Belgium, Estonia, Italy, and Romania), other countries, similar to Germany, assign about a third of board seats to worker representatives (e.g., Austria, Czech Republic, and Denmark). The German requirement that firms with more than 2,000 domestic workers assign half of their board seats to worker representatives represents the largest mandate. "Co-determination" refers to any right that enhances workers active participation in decision-making. In Germany, the participation is twofold. Workers shape decision-making in the boardroom and also participate in works councils to negotiate working conditions (shop floor-level). For an overview of the historical development of co-determination, see McGaughey (2016).
} 
which lowers the cost of goods sold and increases earnings, will be more prevalent when workers are on the board, because workers benefit from the attendant increase in payroll.

We find that worker representation is associated with better monitoring of financial reporting and thus a reduction of agency costs when monitoring duties and payroll maximization incentives are aligned. Our results confirm findings indicating that worker representatives monitor abnormal accruals and reduce extreme abnormal accruals at both ends of the earnings management distribution (Claassen 2016; Overland and Samani 2018). ${ }^{4}$ The inverse U-shaped relation we document aligns with evidence of effective monitoring in the tax setting (Armstrong et al. 2015). We then focus on real earnings management transactions where monitoring duties and payroll maximization incentives are in direct conflict. Consistent with our expectation, we find worker representatives are associated with an increase in production levels for firms in the lower tail of the real earnings management distribution but not with a decrease in overproduction for firms in the upper tail of the distribution. This increase in inventory production increases total wages and job security in the short run. Similarly, we show that worker representation constrains reductions in discretionary administrative expenditures for firms in the upper tail of the real earnings management distribution. We find no corresponding increase in the level of administrative spending cuts in the lower tail of the distribution.

We also expect that workers on corporate boards will constrain aggressive tax planning more for firms where the risk to wage and job security from moving jobs offshore is high. Multinational tax incentives affect where firms move jobs and can lead to offshoring (Williams 2018). We predict that worker representation in those firms where the risk of offshoring is high leads to a decrease in tax aggressiveness for highly aggressive firms. We do not expect worker representation to facilitate a corresponding increase in tax aggressiveness for low-aggression firms.

We find that worker representatives improve board monitoring by reducing under- and over-aggressive tax planning for firms in general. This result is consistent with prior research indicating that governance mechanisms mitigate agency problems related to under- and over-aggressive tax planning (Armstrong et al. 2015). However, this inverse U-shaped relation holds only for firms with a low risk of moving operations offshore. Consistent with our expectation, we continue to find a negative association between worker representation and tax aggressiveness for high-aggression firms with a greater risk of moving firm operations to other jurisdictions. We find no evidence that monitoring leads to an increase in tax aggressiveness for low-aggression firms with a greater risk of moving operations offshore. Our findings suggest that workers on corporate boards block tax strategies and fail to promote tax planning when the risk of offshoring jobs is higher. This result is consistent with the notion that workers on corporate boards maximize payroll for workers when tax transactions impact payroll and job security.

Overall, our results suggest that payroll maximization incentives dominate monitoring duties when the two are in conflict. This result is consistent with expectations, in economic theory, that worker representatives will use their control and voting rights to transform firm assets to private benefits and higher wages (Jensen and Meckling 1979; Furubotn 1988).

\footnotetext{
${ }^{4}$ Earnings management is closely connected to earnings quality. However, we expect that firms have incentives to manage earnings in both tails of the earnings management distribution, i.e., earnings increasing or big-bath accruals. Earnings quality defined as conservative accounting (Ball and Shivakumar 2008) would consider only the upper tail of the distribution.
} 
However, workers are effective monitors when payroll maximization incentives and monitoring duties are aligned, suggesting a more nuanced cost-benefit tradeoff to including them on the board.

This paper makes a number of contributions. First, we contribute to the ongoing public debate, in the United States and United Kingdom, about the economic effects of worker representation and whether or not corporate governance systems should be reformed (e.g., the Guardian 2016; the Wall Street Journal 2018; the New York Times 2019). Our results emphasize the importance of identifying and considering workers' incentives in boardroom decisions, and should help policymakers and regulators evaluate how to include worker representatives in the U.S. corporate governance system.

Second, we extend financial economics research that examines the net benefits of worker representation (e.g., Gorton and Schmid 2004; Fauver and Fuerst 2006; Balsmeier et al. 2013; Petry 2018). Our study is substantially different from prior studies in this area because our setting permits us to differentiate between the workers' monitoring duty and their payroll maximization incentives when jobs or wages are at risk. We find that the benefits of including workers on the board are reduced when monitoring and payroll maximization objectives are in direct conflict.

Third, this study adds to research on agency issues related to different corporate governance structures and the role of boards (e.g., Adams and Ferreira 2007). Our results contribute to the general debate about optimal board compositions to reduce agency costs (e.g., Dahya and McConnell 2007; Linck et al. 2008; Adams et al. 2010; Ahern and Dittmar 2012). We extend this literature by combining research on taxes and real earnings management and the role of boards. We also extend research that examines tax implications of various stakeholders (e.g., Desai et al. 2007; Rego and Wilson 2012; Chyz et al. 2013; Armstrong et al. 2015).

\section{Prior literature and hypotheses}

\subsection{Theory and background}

Economic models of workers on corporate boards highlight the potential conflict between the worker's duty, as a monitor of management, to maximize firm value and the worker's incentive to maximize wages and job security (Jensen and Meckling 1979; Furubotn 1988). These models typically distinguish between shareholders who are beneficiaries of increases in firm value and workers who are compensated from the current resources of the firm (e.g., Alchian and Demsetz 1972; Alchian 1984). A key inference from these models is that allowing workers to influence boardroom decisions without having invested any money in the firm enables them to make decisions at the shareholders' cost. Jensen and Meckling (1979) argue that having workers on boards must be suboptimal, because they rarely observe firms voluntarily including them on boards. Even today, voluntary worker representation is rare. ${ }^{5}$ Jensen and Meckling characterize mandatory inclusion of workers on the board as

\footnotetext{
$\overline{5}$ For example, Walmart shareholders voted 3,916 "for" to 2,379,343,435 "against," rejecting the proposal to put hourly workers on the board (Walmart 8-K filed June 10 2019). However, Chrysler voluntarily assigned a seat to the United Automobile Workers (UAW) president from 1980 to 1991. After the bailout in 2008, a representative of the UAW Retiree Medical Benefits Trust also served on Chrysler and General Motors boards (Bloomberg 2018b).
} 
giving the workers authority to "eat up" the assets of the firm (Jensen and Meckling 1979, 504). By holding control and voting rights, worker representatives can consume firm assets to increase wages and benefits. Workers alter the firm's objectives towards payroll maximization by adding workforce-related issues to the board's agenda and by contributing different perspectives in board debates (Hammer et al. 1991). Consistent with these predictions, empirical studies find worker representation is associated with a decline in firm value (FitzRoy and Kraft 1993; Gorton and Schmid 2004; Petry 2018).

Although worker representation is associated with a decline in firm value, researchers also find that workers on the board improve monitoring and investment decisions, particularly in firms that have a greater need for coordination. Worker representatives add valuable first-hand knowledge to the board, which complements the insights of managers and shareholder representatives (Fauver and Fuerst 2006; Balsmeier et al. 2013). Importantly, workers' monitoring duties and payroll maximization incentives are not in direct conflict in the investment settings because productive investments increase the likelihood of firm survival and thus improve wages and job security. These results speak to the net benefits and costs of worker representation but do not resolve the concern that including workers on the board is likely to reduce firm value (as economic theory predicts). Overall, prior literature on worker representation presents no insights on the direct conflict between the competing incentives of worker representatives. We fill this gap by examining transactions in the real earnings management and tax aggressiveness settings, where workers face competing objectives. Evidence from this direct conflict can reveal the relative importance of monitoring versus payroll maximization. ${ }^{6}$

\subsection{Workers' conflicting incentives}

As monitors, worker representatives are expected to reduce extreme earnings management and tax aggressiveness at both ends of the distribution. For example, using quantile regression, Armstrong et al. (2015) document an inverse U-shaped relation between tax avoidance and "good" governance. ${ }^{7}$ Similarly, effective governance is associated with a reduction in earnings management in both the upper and lower ends of the earnings management distribution (e.g., Klein 2002; Xie et al. 2003; Fan 2007; Visvanathan 2008; Srinidhi et al. 2011; Faleye et al. 2011; Zhao et al. 2012; Ge and Kim 2014; Chen et al. 2015; Cheng et al. 2016; Overland and Samani 2018). ${ }^{8}$ These findings highlight the dual role of effective monitoring - reducing extreme outcomes at both ends of the distribution. ${ }^{9}$ Labor contract models and empirical

\footnotetext{
${ }^{6}$ Conflicting incentives are not limited to workers on boards. Similar potential conflicts exist when other stakeholders, such as banks, major customers or suppliers, are members of the board (Kroszner and Strahan 2001; Byrd and Mizruchi 2005; Hillman et al. 2008; Dittmann et al. 2010).

${ }^{7}$ Relatedly, Minnick and Noga (2010) examine the association between several governance characteristics and tax avoidance at the upper tail of the tax avoidance distribution.

${ }^{8}$ Studies of earnings management often use absolute values, which implicitly test both ends of the distribution. We use quantile regressions to distinguish between conflicting incentives at the upper and lower ends of the distribution. Although researchers have primarily considered continuous measures of accruals and real earnings management, earnings management quantiles have been used in several studies, including Cohen et al. (2014), Greiner et al. (2017), and Feng and Huang (2020).

${ }^{9}$ Tests of differences in real and accrual-based earnings management implicitly assume that firms have similar incentives and ability to manage earnings using these mechanisms. We use a regression discontinuity-design to address concerns that firm attributes rather than incentives motivate earnings management. Our results hold only for the 500 domestic worker threshold for mandatory representation on the board.
} 
evidence are consistent with the notion that worker representatives on boards use their control and voting rights to improve overall board monitoring (Mueller-Jentsch 1995; Freeman and Lazear 1995; Fauver and Fuerst 2006).

Worker representatives are also likely to be concerned about worker pay and job security. However, empirical evidence that worker representatives maximize payroll is inconclusive (FitzRoy and Kraft 1993; Gorton and Schmid 2004; Kim et al. 2018). Effective monitoring is likely to constrain extreme outcomes at both ends of the distribution. In contrast, evidence that worker representatives maximize payroll is evident in one end of the distribution of choices - those choices that lead to higher wages.

To identify workers' conflicting incentives, we focus on a subset of real earnings management and tax transactions that have real effects on, and consequences for, workers' jobs and wages. For example, moving firm operations offshore because of multinational tax incentives can result in larger layoffs (Williams 2018). Similarly, managers can manipulate earnings by increasing production to spread overhead costs over a larger number of units. This reduces the cost of goods sold and increases earnings - which also increases workers' payroll. By analyzing board monitoring of transactions that have a direct impact on workers' payroll, we provide empirical insights into the conflict between workers' monitoring and payroll maximization incentives.

\subsubsection{Real earnings management with wage and job security implications}

Monitoring can reduce real earnings management and improve operating efficiency but may also reduce workers' payroll and job security. ${ }^{10}$ Thus, worker representatives face a potential conflict between their monitoring duty and their incentives to maximize payroll. We focus on two operational decisions: inventory production and discretionary administrative expenditures (e.g., Roychowdhury 2006; Cohen et al. 2008; Cohen and Zarowin 2010; Zang 2012). ${ }^{11}$

Effective monitoring reduces overproduction of inventory at the upper end of the distribution and also increases operating efficiency and thus production at the lower end of the distribution. Workers benefit from overproduction because they work more hours, increasing their pay. Monitoring duties conflict with payroll maximization incentives because workers prefer overproduction and the resulting increase in payroll. At the lower end of the distribution, underproduction implies inefficient operation, risk

\footnotetext{
${ }^{10}$ Consistent with research on both real earnings management and governance (e.g., Cheng et al. 2016), we assume that managers and workers are generally aligned in preferring more earnings to less, except in loss firms, where big baths permit better reports in future periods. Relatedly, managers of German firms engage in earnings management to achieve zero earnings, earnings changes, and analyst forecast benchmarks (e.g., Burgstahler et al. 2006; Daske et al. 2006), and incentives for threshold-oriented earnings management are not different between U.S. and German firms (Glaum et al. 2004).

${ }^{11}$ Managing sales (e.g., one-time price discounts, lenient credit terms) and cuts to R\&D expenditures are two other real earnings management mechanisms examined in the literature. However, the relation between worker representation and managing sales (measured using abnormal CFO levels) and R\&D levels is not clear ex ante. We find (untabulated) that the association between worker representation and abnormal CFO levels is significantly positive in low real earnings management quantiles and insignificant in high real earnings management quantiles, suggesting that worker representatives are less effective at monitoring efforts to increase operating cash flows. For R\&D expenditures, we find an inverse U-shaped relation, consistent with effective monitoring.
} 
aversion, or slack building. We expect monitoring from boards to reduce inefficiencies and slack. Workers benefit from monitoring that increases operating efficiency and production because this too increases wages.

Similarly, effective monitoring can reduce firms' use of extreme cuts to discretionary administrative expenditures. Workers benefit from this monitoring because cuts to administrative expenditures could include reductions in wages or benefits, layoffs, or less training. ${ }^{12}$ At the lower end of the distribution, effective monitors may recommend cuts to discretionary administrative expenditures when budgets are bloated and operations are inefficient. However, monitoring that reduces discretionary administrative expenditures reduces wages and job security for administrative staff.

If payroll maximization incentives dominate monitoring duties, we do not expect to observe an inverse U-shaped relation between worker representation and real earnings management. ${ }^{13}$ When firms manage earnings upward by overproducing inventory, we expect that the worker representatives who are prioritizing payroll maximization over monitoring will not curtail the overproduction. At the lower end of the real earnings management distribution, where production capacity is not being used efficiently, payroll maximization incentives and monitoring duties align. In these firms, worker representatives' personal links to local managers could enable the worker representatives to reduce underproduction on the shop floor, improving operational efficiency and increasing earnings. Thus, we expect worker representation to be associated with increases in production.

Similarly, for firms at the lower end of the real earnings management distribution that have higher administrative expenditures, we do not expect worker representatives to advocate cuts in the level of discretionary administrative expenditures, although their firms are operating less efficiently. The potential for cuts to staff wages, benefits, or training put monitoring duties in conflict with payroll maximization incentives. ${ }^{14}$ At the upper end of the real earnings management distribution, firms aggressively cut administrative expenditures to manage earnings upward. Workers prefer to decrease the cuts to administrative expenses, aligning monitoring duties and payroll maximization incentives. Thus, we expect worker representation to be associated with fewer cuts to discretionary administrative expenditures.

- H1: When monitoring of real earnings management activities increases the risk of job or wage loss, payroll maximization incentives dominate monitoring for firms with worker representation on the board.

\footnotetext{
${ }^{12}$ Roychowdhury (2006) argues that discretionary expenditures, such as SG\&A, often include administrative expenditures such as employee training that increases human capital and the commitment of the workforce (Gunny 2010).

${ }^{13}$ Prior research suggests that the use of (real) earnings management in the current period is constrained by both real and accrual-based earnings management activities in previous periods (e.g., Barton and Simko 2002; Cohen and Zarowin 2010; Zang 2012). In additional tests (untabulated), we add a proxy for balance sheet bloat, defined as an indicator variable equal to one if the lagged net operating assets (calculated as shareholders' equity minus cash and marketable securities plus total debt) scaled by lagged total sales are above the median of the corresponding industry-year, and zero otherwise. In all our tests, our inferences are unchanged when we add this control variable.

${ }^{14}$ In addition, Lin et al. (2019) show that worker representation is associated with an increase in executive compensation. This suggests an alliance between managers and workers that would further diminish worker representatives' support for cuts in administrative expenditures.
} 


\subsubsection{Tax aggressiveness with risk of offshoring production and jobs}

Tax aggressiveness allows us to test whether worker representatives behave differently when transactions that increase earnings threaten workers' payroll and job security. Workers do care that their firms avoid taxes, and they react negatively to news about their firms' tax avoidance activities (Lee et al. 2020). Some aggressive tax planning transactions are particularly salient for workers because they involve the risk of moving jobs to other jurisdictions. Multinational tax incentives lead firms to shift income to low-tax jurisdictions by relocating the firm's real operations (e.g., Collins et al. 1998; Huizinga and Laeven 2008; Klassen and Laplante 2012; Dyreng and Markle 2016). This tax-motivated shifting influences the location of foreign investments, fixed capital, and intangible assets (e.g., Graham et al. 2011; Hanlon et al. 2015). Most important for workers, taxes also influence the decision to offshore jobs (Williams 2018). The impact of taxes on job location is not trivial. The European Parliament conservatively estimates that around 1.5 million jobs could have been supported with the money that was lost to EU member states and their national tax authorities because of tax losses related to activities revealed by the "Panama Papers" (European Parliament 2017).

Estimates suggest that up to $42 \%$ of all German jobs are potentially offshorable to foreign locations (Schrader and Laaser 2009). Between 1999 and 2015, German firms' foreign direct investments increased from $€ 412$ billion to $€ 1,444$ billion (Deutsche Bundesbank 2018), and Germany's increase in offshoring exceeded that of other large European economies (e.g., Beissinger et al. 2016). Although German multinationals claim to invest abroad for cost saving, market development, and sales/customer service (DIHK 2018), recent evidence suggests that tax considerations are particularly important in German firms' offshoring decisions (Goldbach et al. 2017).

We expect that workers on corporate boards are particularly sensitive to aggressive tax planning if this planning includes moving firm operations to other jurisdictions. Anecdotally, German worker representation prevented a firm from establishing or expanding a more profitable production facility abroad (Hans Boeckler Foundation 2004). ${ }^{15}$ Apart from tax-related implications, moving firm operations to other jurisdictions can also be used to weaken or circumvent worker rights, social protection laws, and co-determination regulation (ETUI 2018). Additionally, like U.S. firms, German firms do not appear to share any tax savings with workers. In Germany, workers are unlikely to be compensated via stock option plans, limiting their ability to benefit from an increase in firm value due to aggressive tax planning (Lin et al. 2018). Based on multinational tax incentives and their implications for labor decisions, we expect that worker representatives prefer to block aggressive tax planning that could offshore jobs, aligning their payroll maximization incentives and monitoring duties. For firms doing less tax planning, workers' payroll maximization incentives conflict with monitoring duties. We expect worker representatives will not encourage additional tax planning when the risk of offshoring jobs is high.

\footnotetext{
${ }^{15}$ At Stanley Works, protests by employees and customers prevented the firm from inverting its legal headquarters to a tax haven, a tax planning move the board had approved (Cloyd et al. 2003). We expect that, if worker representatives had been on the board, the inversion decision would have failed a board vote. Worker representatives on the board of the German multinational conglomerate Thyssenkrupp opposed a sale of the elevator unit due to concerns about layoffs, leading the firm to pursue an IPO of the unit instead (Reuters 2019).
} 
- H2: When monitoring of aggressive tax planning increases the risk of job or wage loss, payroll maximization incentives dominate monitoring for firms with worker representation on the board.

\section{German boards, research design and sample}

\subsection{Institutional setting: Structure of German boards}

Fiduciary responsibility resides with all supervisory board members and thus also with any appointed worker representative. Worker representatives are elected by a firm's domestic (i.e., German) workers and represent and protect their interests. ${ }^{16}$ However, all board members also have a legal obligation to maintain the secrecy of information conveyed to the board.

The number of worker representatives a German firm must include on its board depends on the firm's size and legal form. Figure 1 compares and contrasts the two board compositions of German stock corporations that are the focus of our analysis. Panel A shows the board composition of firms with fewer than 500 domestic workers. Firms below this threshold are exempt from worker representation. Like U.S. boards, this board composition only includes shareholders. ${ }^{17}$ Panel B shows firms with more than 500 domestic workers. The Industrial Constitution Act of 1952 and the Third Part Act of 2004 mandate that workers be included in the boardroom when the firm exceeds the threshold of 500 domestic workers. Firms above this threshold must assign one-third of their supervisory board seats to worker representatives (onethird co-determination). ${ }^{18}$

Worker representatives on the boards of German firms are white-collar workers and skilled blue-collar workers, but not unskilled blue-collar workers (Kim et al. 2018). While direct evidence about the financial acumen of workers on the boards is not available, $90 \%$ of the largest German firms have at least one worker representative on the audit committee, and $60 \%$ appoint an equal number of shareholders and worker representatives to the audit committee (Hans Boeckler Foundation 2008; PricewaterhouseCoopers 2009; Drinhausen and Eckstein 2018). The inclusion of

\footnotetext{
${ }^{16}$ All worker representatives are nominated by a firm's domestic workers. German law defines workers as employees who earn wages collectively agreed to by labor unions and employer associations. Workers vote for their representatives directly or through delegates if the number of workers is very large. Directors and executives who have the power to represent the company are excluded from voting or being elected to represent workers.

${ }^{17}$ German firms rarely include workers on boards voluntarily. We hand-collect the number of domestic jobs from annual reports to investigate how many firms voluntarily include worker representatives. Within our real earnings management (tax) sample, 23 of 214 firms (25 of 203 firms) have worker representation when the number of German workers is below 500, which is in line with percentages in prior research. As a robustness test, we exclude the abovementioned firms and repeat our analyses. Our inferences are unchanged.

${ }^{18}$ German firms have few loopholes that would allow them to circumvent worker representation. German public firms under the legal form of a European Corporation (i.e., Societas Europaea) can define, in their articles of incorporation, whether they have worker representation. Asset-management holding companies (non-operating holdings) need not include worker representatives. Our results are robust to excluding 105 firm-years in the real earnings management sample and 68 firm-years in the tax sample (about $10 \%$ of each sample) in which the firm has more than 500 German workers but no worker representation. These 68 firmyears represent 29 firms: seven firms are European Corporations, one firm is an asset-management holding firm, and 21 firms (52 firm-years) do not incorporate worker representatives for reasons that are not obvious. This distribution is very similar in the real earnings management sample. Excluding these firms does not change our inferences.
} 
A Non-co-determined board

Shareholder Representatives

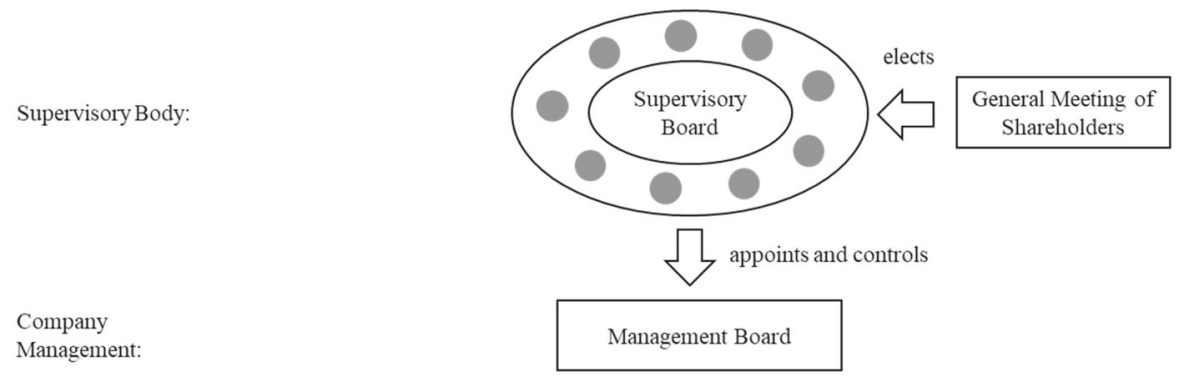

B One-third co-determination

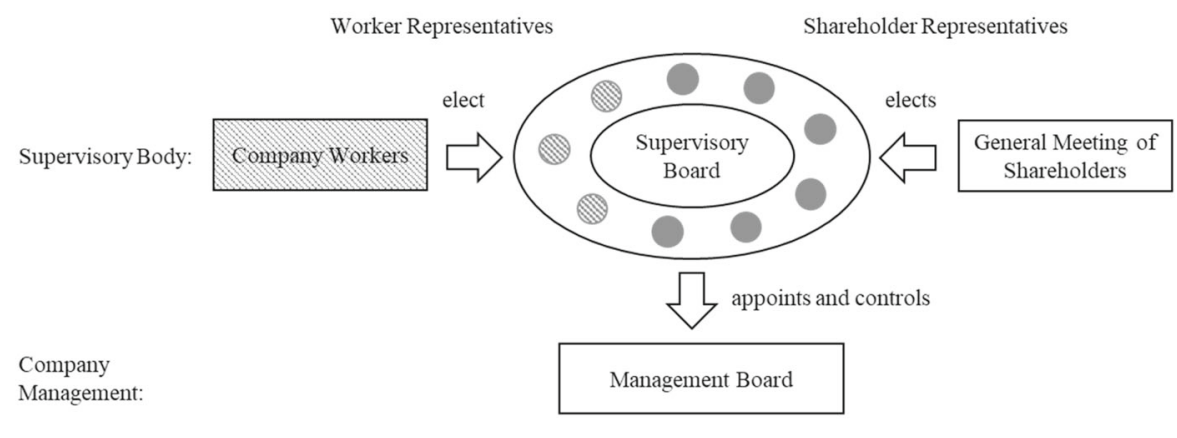

Fig. 1 Board-level worker representation. Sizes of boards are illustrative. For example, in the tax sample the average number of board members for firms with no worker representatives is 3.6 with a range of three to nine members. Firms with one-third co-determination average 5.6 board members with a range of three to 11 members

worker representatives on the audit committee suggests that they are viewed as sufficiently sophisticated to monitor financial reporting. In addition, German labor organizations provide detailed training and hold seminars on accounting topics to educate worker representatives and enable them to monitor accounting decisions. ${ }^{19}$

\subsection{Research design}

Our research design exploits the requirement that firms with more than 500 domestic workers include worker representatives on the board. We restrict our sample to firms that have no more than 1,000 domestic workers. This allows us to directly relate our results to the effect of worker representation and to reduce the influence of differences between firms with and without worker representation.

\footnotetext{
${ }^{19}$ Current topics covered by labor organizations' seminars include the structure of annual and consolidated financial statements; discussions of how the balance sheet, income statement, and cash flow statement are connected; training on IFRS reporting (e.g., pension provisions, deferred taxes, and goodwill); and methods of balance sheet policy and risk assessment (e.g., Hans Boeckler Foundation 2019; German Trade Union Confederation 2019).
} 
To test hypothesis 1, we estimate Equation (1):

$$
\begin{aligned}
& \text { REM }_{i, t}=\beta_{0}+\beta_{1} \text { WORKER_REP }_{i, t}+\beta_{2} \text { SIZE }_{i, t}+\beta_{3} M_{T B}+\beta_{4} N E T \_I N C O M E_{i, t} \\
& +\beta_{5} L E V_{i, t}+\beta_{6} \text { LOSS }_{i, t}+\beta_{7} \text { WORKS_COUNCIL } \\
& + \text { YEAR } \\
& + \text { YEAR_FE }+\varepsilon_{i, t} \text { GOV }_{i, t}
\end{aligned}
$$

We measure real earnings management, $R E M$, with two proxies: inventory production ( $\left.A B N_{-} P R O D\right)$ and discretionary administrative expenditures $\left(A B N \_A D M I N\right)$. Following Roychowdhury (2006), $A B N \_P R O D$ equals the actual production costs minus the average industry-year production costs, and $A B N \_A D M I N$ equals the actual discretionary administrative expenses minus the average industry-year discretionary administrative expenses. ${ }^{20} \mathrm{We}$ multiply $A B N \_A D M I N$ by negative one (e.g., Cohen and Zarowin 2010; Zang 2012), so that positive values represent more income-increasing earnings management for both measures.

The primary independent variable is WORKER_REP, an indicator variable that equals one if the board of a firm includes workers and zero otherwise. Hypothesis 1 predicts $\beta_{1}$ is significantly positive for low-level real earnings management firms when $A B N \_P R O D$ is the dependent variable. This expectation comports with the notion that payroll maximization incentives and monitoring duties are aligned and lead firms to increase production levels when workers are on the board. For highlevel real earnings management firms, however, we predict $\beta_{1}$ will be insignificant or positive because we expect the job and wage benefits from overproduction to dominate monitoring duties.

When $A B N \_A D M I N$ is the dependent variable, we expect $\beta_{1}$ to be significantly negative for high-level real earnings management firms. This expectation is consistent with workers on corporate boards blocking cuts to discretionary administrative expenditures, including cuts to staff wages, benefits and training. However, for low-level real earnings management firms, where payroll maximization incentives and monitoring duties conflict, we do not expect workers to advocate for cuts to discretionary administrative expenditures that could result in job losses (i.e., $\beta_{1}$ should be insignificant or negative).

Based on prior literature, we control for size $(S I Z E)$ and growth opportunities $(M T B) . S I Z E$ is defined as the logarithm of market value of equity at the beginning of the year. MTB is market capitalization divided by book value of equity at the beginning of the year. We include net income scaled by lagged total assets (NET_INCOME) to control for performance. We control for leverage ( $L E V$ equal to long-term debt plus current debt scaled by total assets) because Lin et al. (2018) document an association between workers on the board and leverage. For the period from 1991 to 1993, Gorton and Schmid (2004) find an association between firm value and leverage. However, the German corporate tax reform in 2000 repealed the capital gains tax on sales of corporate crossholdings (Edwards et al. 2004). Banks and firms responded by reducing their equity holdings, significantly reducing banks' influence (Weber 2009). Fauver and Fuerst (2006) find no association between leverage and firm value for their post-reform sample; hence,

\footnotetext{
${ }^{20}$ See Appendix 1 for detailed information regarding the calculation of $A B N_{-} P R O D$ and $A B N_{-} A D M I N$.
} 
we do not make a prediction on the sign of the coefficient. ${ }^{21} \mathrm{We}$ also control for firm-years with a negative pre-tax book income (LOSS), because managers are motivated to avoid reporting losses. We include WORKS_COUNCIL, which is equal to one if the proportion of firms in the industry with a works council is above the median of all industries and zero otherwise. Prior literature suggests that works councils have information rights and consultation rights, which improve communication between workers and management and increase operating efficiency (Freeman and Lazear 1995; FitzRoy and Kraft 2005). ${ }^{22}$ Finally, we control for a firm's governance quality $(G O V)$ to isolate the specific influence of worker representatives in our tests. We construct a summary score of governance quality that combines board size, audit committee size, and number of board meetings (DeFond et al. 2005). ${ }^{23} \mathrm{GOV}$ is equal to one if the sum of the three dichotomous governance variables is greater than the sample median, and zero otherwise. We also include year fixed effects. ${ }^{24}$

To test hypothesis 2, we estimate Equation (2):

$$
\begin{aligned}
& \text { ETR_DIFF } F_{i, t}=\beta_{0}+\beta_{1} \text { WORKER_REP_FSALES_LOW } \\
& +\beta_{2} \text { WORKER_REP_FSALES_HIGH } H_{i, t}+\beta_{3} S_{I Z E_{i, t}}+\beta_{4} R O A_{i, t} \\
& +\beta_{5} P_{P P E_{i, t}}+\beta_{6} \text { INTAN }_{i, t}+\beta_{7} L E V_{i, t}+\beta_{8} A_{T R R_{i, t}}+\beta_{9} \text { CAPEX }_{i, t} \\
& +\beta_{10} R \& D_{i, t}+\beta_{11} \text { WORKS_COUNCIL }_{i, t}+\beta_{12} \text { GOV }_{i, t} \\
& +Y E A R \_F E+\varepsilon_{i, t}
\end{aligned}
$$

We measure ETR_DIFF as the average industry-size GAAP ETR less a firm's GAAP $E T R .^{25}$ Average industry-size ETR equals aggregate tax expense for the portfolio of firms from the same industry (using two-digit GICS codes) and same quintile of total assets, divided by aggregate pre-tax income (Balakrishnan et al. 2019). ${ }^{26}$ Using industry-size adjusted effective tax rates is most suitable for our research question.

\footnotetext{
${ }^{21}$ Prior studies have also included controls for bank representation. However, measures of bank ownership are insignificantly associated with firm value in more recent periods, possible due to a decline in in bank representation and bank ownership after capital gains tax reform in 2002 (Fauver and Fuerst 2006; Dittmann et al. 2010). Additionally, measures of bank ownership and membership on boards do not reflect banks' proxy voting rights (Gorton and Schmid 2000). Thus, we follow Gorton and Schmid (2004) and Fauver and Fuerst (2006) and do not further consider proxy voting rights in our analysis.

${ }^{22}$ Information on works council coverage by industry is obtained from the German Institute of Employment Research of the Federal Employment Agency (Dribbusch and Birke 2019, p. 14).

${ }^{23}$ Aggregate measures of corporate governance are easier to compare than several individual measures (DeFond et al. 2005). Nevertheless, our inferences are robust to including the natural logarithms of board size, audit committee size, and number of board meetings. In additional tests, we also include the number of board committees and the number of audit committee meetings in our measure for governance quality. Although both attributes are highly correlated with audit committee size, the inferences are unchanged.

${ }^{24}$ All continuous variables in our tests are winsorized at the top and bottom one percent of their respective distributions. Our results are also robust to using industry-year adjusted control variables.

${ }^{25}$ This measure assumes that the industry-average level of tax-reducing activities is available to all firms in the industry. In the German setting, other tax aggressiveness proxies commonly used in U.S. research, such as the likelihood of entering into tax shelters (Wilson 2009; Lisowsky 2010), tax haven activities (Dyreng and Lindsey 2009; Law and Mills 2017), discretionary permanent book-tax differences (Frank et al. 2009), and uncertain tax benefits recorded under FIN 48 (De Waegenaere et al. 2015), are infeasible. However, Blouin (2014) and Balakrishnan et al. (2019) point out that each of these measures has limitations and only partially captures a firm's overall tax aggressiveness.

${ }^{26}$ Our inferences are unchanged if we adjust ETRs for the industry average only (i.e., not adjusting for firm size).
} 
Benchmarking the ETRs to peers captures board monitoring better than raw ETRs (Armstrong et al. 2015; Chyz and Gaertner 2018). Worker representatives could easily compare their firm's ETR and that of their industry and size peers. Our measure benchmarks a firm's aggressiveness to "typical" tax planning and thus accounts for this potential means of monitoring. Positive values of ETR_DIFF indicate that the firm reports less tax expense than its industry and size peers, which we interpret as greater tax aggressiveness.

To test hypothesis 2, we use foreign sales as a percentage of total sales (Jacob 1996) to proxy for the likelihood that tax planning increases the risk that a firm moves jobs offshore. We hand collect foreign sales from segment disclosures in annual reports. We select this proxy for several reasons. First, we assume that a firm begins its multinational business strategy by selling products in foreign countries. These transactions are highly visible and recognizable for a firm's workforce and thus fit our research question. Second, we expect workers on corporate boards to be attentive to the possibility of foreign operations before jobs are actually shifted offshore. Accordingly, we measure the likelihood of moving firm operations offshore instead of the actual degree of previously executed shifting. In additional tests, we confirm our inferences are robust to using alternative measures of the likelihood of offshoring.

In Equation (2), we use two variables that jointly capture the level of a firm's foreign sales and whether a firm's board includes worker representation: (1) WORKER_REP_FSALES_LOW equals one if the board of a firm includes workers and if the firm reports foreign sales to total sales below the median and zero otherwise; and (2) WORKER_REP_FSALES_HIGH equals one if the board of a firm includes workers and if the firm reports foreign sales to total sales above the median and zero otherwise. We expect an inverse U-shaped relation between tax aggressiveness and WORKER_REP for firms with a low risk of moving jobs offshore. Specifically, we expect $\beta_{1}$ to be negative for firms in the upper tail of the tax aggressiveness distribution and positive for firms in the lower tail of the distribution. Hypothesis 2 implies a negative association between worker representation and tax aggressiveness $\left(\beta_{2}\right)$ for firms in the upper tail of the tax aggressiveness distribution. However, when the risk of moving jobs offshore is high, we do not expect worker representatives to promote an increase in tax aggressiveness for firms in the lower tail of the tax aggressiveness distribution. Thus, we predict an insignificant or negative sign on $\beta_{2}$ in the lower tail of the distribution.

Following prior research, we control for firm characteristics that tax research has identified as important determinants of tax avoidance (e.g., Gupta and Newberry 1997; Mills et al. 1998; Rego 2003; Oler et al. 2007; Frank et al. 2009; Chen et al. 2010; Rego and Wilson 2012; Badertscher et al. 2019). To minimize concerns that our results are driven by firm size, we control for SIZE, as defined in Eq. (1). Return on assets $(R O A)$ is defined as pre-tax income scaled by total assets and controls for a firm's profitability. We include net property, plant, and equipment $(P P E)$ and intangible assets (INTAN), both scaled by total assets, to control for different book-tax treatments for noncurrent tangible and intangible assets. Leverage $(L E V)$ equals long-term debt plus current debt scaled by total assets. We control for asset turnover $(A T R)$, defined as total sales divided by total assets. Additionally, we control for capital expenditures (CAPEX) and R\&D expenditures $(R \& D)$, both scaled by total assets. Our controls also address 
potential nontax reasons for differences in operations that affect tax. ${ }^{27}$ Similar to the real earnings management setting, we control for works council coverage $\left(W O R K S \_C O U N C I L\right)$ and governance quality $(G O V)$ as defined in Eq. (1). We also include year fixed effects.

We estimate our regressions using quantile regression, rather than OLS, because we are interested in the association between worker representation and real earnings management and tax transactions in the tails of the dependent variable's distribution. OLS estimates the association between independent variables and the conditional mean of the dependent variable. In our context, OLS measures how "on average" worker representation is associated with real earnings management or tax aggressiveness. In contrast, quantile regression estimates the effect of independent variables on the dependent variable for conditional quantiles of the dependent variable's conditional distribution (Koenker and Bassett 1978; Koenker and Hallock 2001). Examples from economics and finance literature show that investigating the conditional mean of the dependent variable's distribution provides a rather "incomplete picture" (Mosteller and Tukey 1977, p. 266). ${ }^{28}$ Using quantile regression allows us to evaluate non-central locations at the real earnings management and tax aggressiveness distributions and, therefore, to provide more precise implications.

\subsection{Sample selection}

Table 1, Panel A summarizes sample selection for our real earnings management dataset (hypothesis 1). The initial sample is 5,622 firm-year observations for publicly traded German firms in Compustat Global over the 2009-2015 sample period, representing 942 unique firms. Following Roychowdhury (2006) and others, we exclude 1,545 observations for which we have fewer than 15 observations per industry and year. We exclude 1,846 observations that are missing data for the control variables in Compustat, and 290 observations that are missing corporate governance data, which we hand-collect from annual reports. We also hand-collect the number of domestic workers from annual reports to examine the discontinuity at the legal threshold of 500 domestic workers. We restrict the sample to firms with fewer than 1,000 domestic workers. This leads to our final real earnings management sample of 978 firm-years from 214 unique firms. We limit the sample for our abnormal production tests to manufacturing firms in consumer discretionary, industrials, and materials industries that are likely to employ workers in production roles. This yields a restricted subsample of 235 firm-years.

Our sample for the tests of tax aggressiveness (hypothesis 2) also begins with 5,622 firm-years (Table 1, Panel B). We exclude 3,055 observations that have negative pretax income or that are missing the Compustat data required for computing our tax

\footnotetext{
${ }^{27}$ Our results are robust to using industry-size adjusted control variables in the regression. Our results are also robust to including supervisory board directors' compensation as a control. However, we do not include this variable in our main tests because requiring this data substantially reduces our sample.

${ }^{28}$ Economics and finance research has intensively applied quantile regression to detect effects of the independent variables at other points in the dependent variable's distribution than the conditional mean (e.g., Buchinsky 1994; Buchinsky 1998; Eide and Showalter 1998; Bassett and Chen 2001).
} 
Table 1 Sample selection

\section{Panel A: Real earnings management sample}

\section{Criteria}

Full sample: All Compustat Global

firm-years between 2009 and 2015

With less than 15 observations per industry and year

With missing values for control variables

With uncollectable corporate governance data

With less than 1,000 domestic workers

Manufacturing firms in consumer discretionary, industrials, and materials industries for $A B N \_P R O D$ tests

\section{Panel B: Tax sample}

\section{Criteria}

Full sample: All Compustat Global

firm-years between 2009 and 2015

With pre-tax income of less than zero

With missing values for control variables

Excluding all financial firm-years

With GAAP ETRs greater one

With uncollectable corporate governance data

With uncollectable foreign sales data

$(-152)=1,739$

With less than 1,000 domestic workers

$(-1,069)=670$

Notes: In Table 1, we report the sample selection process for the real earnings management sample (Panel A) and tax sample (Panel B). The sample covers the period 2009-2015. All financial statement data except foreign sales are acquired from the annual fundamentals database produced by Compustat Global (German firms)

aggressiveness and control variables. ${ }^{29}$ These requirements reduce the sample to 2,567 firm-years. Additionally, we exclude financial institutions, firm-years with GAAP ETRS greater than one, and firm-years with uncollectable corporate governance data. ${ }^{30}$ These criteria result in a sample of 1,891 firm-years. We hand-collect foreign sales from segment disclosures in annual reports and exclude observations with uncollectable foreign sales data. Finally, we also restrict the tax sample to firms with fewer than

\footnotetext{
${ }^{29}$ We follow prior ETR-based tax research and eliminate loss years; therefore, our results do not apply to loss years. However, in a robustness test, we restrict our tax sample to firms that report positive pre-tax income in each year during 2009-2015, as NOL carryforwards of German firms are not disclosed. Our sample decreases from 670 firm-years to 199 firm-years. Our results (hypothesis 2) remain similar (albeit weaker). We conclude that it is unlikely that our inferences are driven by loss firms.

${ }^{30}$ Following prior research, we include profit and loss firms in our tax sample to avoid bias, but truncate GAAP ETRs at zero and one to avoid the influence of outliers (e.g., Dyreng et al. 2008; Armstrong et al. 2015; Guenther et al. 2017).
} 
1,000 domestic workers to examine the discontinuity around the threshold of 500 domestic workers. This leads to our tax sample of 670 firm-years corresponding to 203 German firms. ${ }^{31}$

\section{Results and robustness tests}

\subsection{Descriptive statistics and univariate tests}

Table 2, Panel A.1 reports descriptive statistics for the full real earnings management sample (978 firm-years), which consists of 215 firm-years with and 763 firm-years without worker representation. We find no significant mean differences in our main variables of interest (i.e., $A B N \_P R O D$, and $A B N \_A D M I N$ ) between firms with and without worker representation. This finding supports our intuition that the effects of worker representation may not relate to the mean of the dependent variable's distribution, and indicates that using quantile regression is a particularly well-suited methodology for our research question. For completeness, we also measure signed abnormal accruals $\left(A B N \_A C C\right)$ from the original Jones model (Jones 1991; Hribar and Nichols 2007). Firms with and without worker representation report similar levels of abnormal accruals. Additionally, we find that firms with worker representation are not significantly different from firms without worker representation with respect to firm size $(S I Z E)$, reducing concerns about the influence of firm size in this setting. Firms with and without worker representation also have similar growth opportunities (MTB). However, we find that firms with worker representation are more profitable (NET_INCOME and LOSS) and have lower leverage (LEV) than firms without worker representation. Firms with worker representation are also significantly less likely to have works councils in their industry, and they have lower governance quality $(G O V)$. We control for these differences in our analyses.

Table 2, Panel A.2 reports descriptive statistics for the subsample of 235 manufacturing firm-years we use for our abnormal production tests. Firms without worker representation have significantly lower levels of abnormal production than firms with worker representation. Abnormal production is measured relative to industry norms, which mitigates concerns that the difference reflects industry composition. Additionally, firms with and without worker representation are the same SIZE, on average. Differences in control variables are consistent with the full sample.

Table 2, Panel B reports descriptive statistics for our tax sample, which includes 217 firm-years with worker representation and 453 firm-years without it. Firms without workers on the board report significantly lower ETRs (27.6\%), on average, than firms with workers on the board (30\%). This difference likely reflects industry and size effects. We find no significant mean difference in industry and size adjusted ETRs $\left(E T R \_D I F F\right)$ for firms with and without worker representation. Again, there is no significant mean difference in firm size (SIZE). Firms without worker representation are more profitable $(R O A)$ than firms with worker representation. The difference in relative profitability between the real earnings management and tax samples likely reflects the exclusion of loss firms from the tax sample. Firms with worker representation have

$\overline{31}$ There is an overlap in both of 440 firm-years (i.e., 131 firms). 
Table 2 Descriptive statistics

\begin{tabular}{lrrrrrrr}
\hline Panel A.1: Real earnings management full sample & & & & \\
& N & Mean & S.D. & p25 & p50 & p75 & Diff. \\
ABN_PROD & 978 & -0.002 & 0.198 & -0.118 & 0.006 & 0.118 & \\
No Workers & 763 & -0.004 & 0.200 & -0.125 & 0.007 & 0.122 & -0.010 \\
Workers & 215 & 0.006 & 0.188 & -0.109 & 0.003 & 0.098 & $(-0.69)$ \\
ABN_ADMIN & 978 & 0.005 & 0.159 & -0.073 & 0.021 & 0.107 & \\
No Workers & 763 & 0.010 & 0.164 & -0.070 & 0.028 & 0.121 & 0.019 \\
Workers & 215 & -0.009 & 0.135 & -0.079 & 0.001 & 0.086 & $(1.54)$ \\
ABN_ACC & 978 & -0.008 & 0.109 & -0.059 & -0.007 & 0.043 & \\
No Workers & 763 & -0.007 & 0.115 & -0.061 & -0.003 & 0.048 & 0.003 \\
Workers & 215 & -0.010 & 0.085 & -0.053 & -0.014 & 0.032 & $(0.31)$ \\
SIZE & 978 & 17.533 & 1.367 & 16.687 & 17.528 & 18.374 & \\
No Workers & 763 & 17.504 & 1.373 & 16.655 & 17.494 & 18.279 & -0.134 \\
Workers & 215 & 17.638 & 1.343 & 16.831 & 17.699 & 18.554 & $(-1.27)$ \\
MTB & 978 & -0.709 & 82.232 & 0.970 & 1.515 & 2.579 & \\
No Workers & 763 & -1.458 & 93.092 & 1.003 & 1.580 & 2.768 & -3.409 \\
Workers & 215 & 1.951 & 2.277 & 0.825 & 1.431 & 2.078 & $(-0.54)$ \\
NET_INCOME & 978 & -0.007 & 0.222 & -0.022 & 0.027 & 0.071 & \\
No Workers & 763 & -0.017 & 0.248 & -0.034 & 0.029 & 0.073 & $-0.046 * * *$ \\
Workers & 215 & 0.029 & 0.070 & 0.003 & 0.027 & 0.064 & $(-2.68)$ \\
LEV & 978 & 0.166 & 0.217 & 0.000 & 0.108 & 0.255 & \\
No Workers & 763 & 0.174 & 0.235 & 0.001 & 0.102 & 0.261 & $0.036 * *$ \\
Workers & 215 & 0.138 & 0.134 & 0.000 & 0.121 & 0.230 & $(2.17)$ \\
LOSS & 978 & 0.310 & 0.463 & 0.000 & 0.000 & 1.000 & \\
No Workers & 763 & 0.333 & 0.472 & 0.000 & 0.000 & 1.000 & $0.105 * * *$ \\
Workers & 215 & 0.228 & 0.420 & 0.000 & 0.000 & 0.000 & $(2.95)$ \\
WORKS_COUNCIL & 978 & 0.219 & 0.414 & 0.000 & 0.000 & 0.000 & \\
No Workers & 763 & 0.252 & 0.434 & 0.000 & 0.000 & 1.000 & $0.150 * * *$ \\
Workers & 215 & 0.102 & 0.304 & 0.000 & 0.000 & 0.000 & $(4.73)$ \\
GOV No Workers & 763 & 0.422 & 0.494 & 0.000 & 0.000 & 1.000 & $0.259 * * *$ \\
Workers & 215 & 0.163 & 0.370 & 0.000 & 0.000 & 0.000 & $(7.15)$
\end{tabular}

Panel A.2: Real earnings management - Abnormal production subsample limited to manufacturing firms

$\begin{array}{clrrrrrr} & \text { N } & \text { Mean } & \text { S.D. } & \text { p25 } & \text { p50 } & \text { p75 } & \text { Diff. } \\ A B N \text { _PROD } & 235 & -0.015 & 0.166 & -0.113 & -0.022 & 0.070 & \\ \text { No Workers } & 155 & -0.041 & 0.156 & -0.150 & -0.034 & 0.056 & -0.076^{* * * *} \\ \text { Workers } & 80 & 0.035 & 0.173 & -0.084 & 0.011 & 0.087 & (-3.39) \\ \text { SIZE } & 235 & 17.646 & 1.433 & 16.979 & 17.681 & 18.355 & \\ \quad \text { No Workers } & 155 & 17.651 & 1.439 & 17.142 & 17.688 & 18.338 & 0.013 \\ \quad \text { Workers } & 80 & 17.638 & 1.431 & 16.821 & 17.527 & 18.530 & (0.07) \\ \text { MTB } & 235 & 2.316 & 3.548 & 0.815 & 1.416 & 2.401 & \end{array}$


Table 2 (continued)

\begin{tabular}{|c|c|c|c|c|c|c|c|}
\hline No Workers & 155 & 2.516 & 4.031 & 0.948 & 1.580 & 2.495 & 0.588 \\
\hline Workers & 80 & 1.928 & 2.320 & 0.630 & 1.188 & 2.068 & $(1.20)$ \\
\hline NET_INCOME & 235 & -0.003 & 0.252 & -0.027 & 0.022 & 0.071 & \\
\hline No Workers & 155 & -0.022 & 0.303 & -0.053 & 0.013 & 0.066 & -0.057 \\
\hline Workers & 80 & 0.035 & 0.090 & 0.001 & 0.030 & 0.084 & $(-1.64)$ \\
\hline$L E V$ & 235 & 0.250 & 0.283 & 0.071 & 0.196 & 0.344 & \\
\hline No Workers & 155 & 0.299 & 0.324 & 0.084 & 0.259 & 0.404 & $0.144 * * *$ \\
\hline Workers & 80 & 0.155 & 0.137 & 0.012 & 0.144 & 0.255 & (3.79) \\
\hline LOSS & 235 & 0.336 & 0.473 & 0.000 & 0.000 & 1.000 & \\
\hline No Workers & 155 & 0.394 & 0.490 & 0.000 & 0.000 & 1.000 & $0.169^{* * *}$ \\
\hline Workers & 80 & 0.225 & 0.420 & 0.000 & 0.000 & 0.000 & $(2.62)$ \\
\hline WORKS_COUNCIL & 235 & 0.204 & 0.404 & 0.000 & 0.000 & 0.000 & \\
\hline No Workers & 155 & 0.277 & 0.449 & 0.000 & 0.000 & 1.000 & $0.214 * * *$ \\
\hline Workers & 80 & 0.063 & 0.244 & 0.000 & 0.000 & 0.000 & (3.99) \\
\hline GOV & 235 & 0.315 & 0.465 & 0.000 & 0.000 & 1.000 & \\
\hline No Workers & 155 & 0.432 & 0.497 & 0.000 & 0.000 & 1.000 & $0.345^{* * *}$ \\
\hline Workers & 80 & 0.087 & 0.284 & 0.000 & 0.000 & 0.000 & $(5.74)$ \\
\hline
\end{tabular}

Panel B: Tax sample

\begin{tabular}{|c|c|c|c|c|c|c|c|}
\hline & $\mathbf{N}$ & Mean & S.D. & p25 & p50 & p75 & Diff. \\
\hline ETR & 670 & 0.284 & 0.162 & 0.201 & 0.291 & 0.339 & \\
\hline No Workers & 453 & 0.276 & 0.169 & 0.180 & 0.287 & 0.337 & $-0.024^{*}$ \\
\hline Workers & 217 & 0.300 & 0.137 & 0.256 & 0.298 & 0.342 & $(-1.88)$ \\
\hline ETR_DIFF & 670 & 0.001 & 0.154 & -0.057 & 0.006 & 0.077 & \\
\hline No Workers & 453 & 0.006 & 0.163 & -0.060 & 0.016 & 0.097 & 0.016 \\
\hline Workers & 217 & -0.010 & 0.133 & -0.048 & -0.004 & 0.047 & (1.22) \\
\hline SIZE & 670 & 17.949 & 1.368 & 16.979 & 17.839 & 18.751 & \\
\hline No Workers & 453 & 17.955 & 1.425 & 16.902 & 17.790 & 18.754 & 0.017 \\
\hline Workers & 217 & 17.938 & 1.242 & 17.149 & 17.974 & 18.708 & $(0.15)$ \\
\hline$R O A$ & 670 & 0.095 & 0.088 & 0.039 & 0.069 & 0.125 & \\
\hline No Workers & 453 & 0.104 & 0.097 & 0.044 & 0.072 & 0.136 & $0.027 * * *$ \\
\hline Workers & 217 & 0.077 & 0.062 & 0.032 & 0.060 & 0.108 & (3.71) \\
\hline$P P E$ & 670 & 0.199 & 0.214 & 0.031 & 0.119 & 0.292 & \\
\hline No Workers & 453 & 0.152 & 0.194 & 0.024 & 0.075 & 0.188 & $-0.144 * * *$ \\
\hline Workers & 217 & 0.296 & 0.223 & 0.149 & 0.235 & 0.426 & $(-8.56)$ \\
\hline INTAN & 670 & 0.143 & 0.175 & 0.015 & 0.067 & 0.227 & \\
\hline No Workers & 453 & 0.179 & 0.193 & 0.022 & 0.116 & 0.283 & $0.111 * * *$ \\
\hline Workers & 217 & 0.068 & 0.092 & 0.009 & 0.034 & 0.080 & $(8.07)$ \\
\hline$L E V$ & 670 & 0.161 & 0.174 & 0.001 & 0.115 & 0.257 & \\
\hline No Workers & 453 & 0.166 & 0.185 & 0.002 & 0.109 & 0.262 & 0.016 \\
\hline Workers & 217 & 0.150 & 0.149 & 0.000 & 0.127 & 0.234 & (1.15) \\
\hline$A T R$ & 670 & 1.206 & 0.735 & 0.755 & 1.110 & 1.403 & \\
\hline No Workers & 453 & 1.189 & 0.818 & 0.735 & 1.073 & 1.387 & -0.051 \\
\hline Workers & 217 & 1.240 & 0.522 & 0.908 & 1.200 & 1.428 & $(-0.84)$ \\
\hline
\end{tabular}


Table 2 (continued)

\begin{tabular}{|c|c|c|c|c|c|c|c|}
\hline CAPEX & 670 & 0.646 & 1.874 & 0.119 & 0.235 & 0.490 & \\
\hline No Workers & 453 & 0.833 & 2.232 & 0.162 & 0.338 & 0.587 & $0.580 * * *$ \\
\hline Workers & 217 & 0.253 & 0.474 & 0.094 & 0.148 & 0.240 & (3.79) \\
\hline$R \& D$ & 670 & 0.029 & 0.055 & 0.000 & 0.000 & 0.031 & \\
\hline No Workers & 453 & 0.033 & 0.062 & 0.000 & 0.000 & 0.034 & $0.013 * * *$ \\
\hline Workers & 217 & 0.020 & 0.035 & 0.000 & 0.000 & 0.022 & $(3.00)$ \\
\hline WORKS_COUNCIL & 670 & 0.173 & 0.379 & 0.000 & 0.000 & 0.000 & \\
\hline No Workers & 453 & 0.196 & 0.398 & 0.000 & 0.000 & 0.000 & $0.072 * *$ \\
\hline Workers & 217 & 0.124 & 0.331 & 0.000 & 0.000 & 0.000 & $(2.31)$ \\
\hline$G O V$ & 670 & 0.339 & 0.474 & 0.000 & 0.000 & 1.000 & \\
\hline No Workers & 453 & 0.391 & 0.488 & 0.000 & 0.000 & 1.000 & $0.161 * * *$ \\
\hline Workers & 217 & 0.230 & 0.422 & 0.000 & 0.000 & 0.000 & $(4.15)$ \\
\hline FOREIGN_SALES & 670 & 0.384 & 0.301 & 0.110 & 0.373 & 0.607 & \\
\hline No Workers & 453 & 0.397 & 0.319 & 0.102 & 0.354 & 0.685 & 0.040 \\
\hline Workers & 217 & 0.357 & 0.258 & 0.119 & 0.420 & 0.578 & $(1.60)$ \\
\hline
\end{tabular}

Notes: In Panel A.1 and Panel A.2 (Panel B), we report descriptive statistics for the main variables used in the real earnings management (tax) sample. Panel A.2 is restricted to manufacturing firms. The last column reports the difference in means between firms with and without worker representation and the $t$-statistic for mean differences. $*, * *$, and $* * *$ indicate significant mean differences at $10 \%, 5 \%$, and $1 \%$, respectively. All variables are defined in Appendix 1

higher levels of fixed assets (PPE) and lower levels of intangible assets (INTAN) than firms without worker representation. However, firms with and without worker representation have similar levels of leverage (LEV) and asset turnover (ATR), indicating similar creditor influence and asset productivity. Firms with worker representation have lower levels of both capital expenditures $(C A P E X)$ and $\mathrm{R} \& \mathrm{D}$ expenditures $(R \& D)$ than firms without worker representation. Firms with worker representation are also less likely to operate in industries with a greater incidence of works councils (WORKS_COUNCIL), and they have lower governance quality $(G O V)$. We control for these differences in our analysis. Importantly for hypothesis 2, we find that firms with and without worker representation report similar levels of foreign sales (FOREIGN_SALES).

In Table 3, we report Pearson (Spearman) correlations below (above) the diagonal for the real earnings management sample (Panel A) and the tax sample (Panel B). The Spearman univariate correlations with WORKER_REP are most appropriate because WORKER_REP is dichotomous. WORKER_REP is correlated with $A B N \_A D M I N$ and not significantly associated with $A B N \_P R O D, A B N \_A C C$, and ETR_DIFF. Our real earnings management variables, $A B N \_P R O D$ and $A B N \_A D M I N$, are correlated with SIZE, NET_INCOME, and LOSS (Panel A). Additionally, ETR_DIFF is correlated with ROA, PPE, INTAN, and CAPEX (Panel B).

\subsection{Results of real earnings management tests}

Before we test hypothesis 1 , we document the general relation between worker representation and monitoring of financial reporting. Our results confirm that the relation between worker representation and abnormal accruals is an inverse U-shape. 


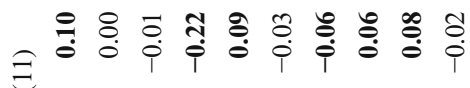

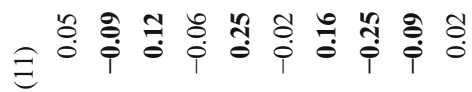

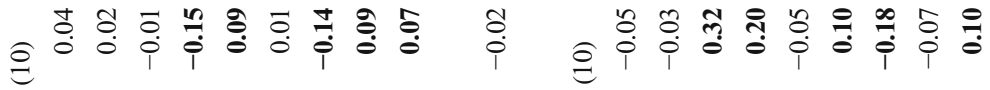

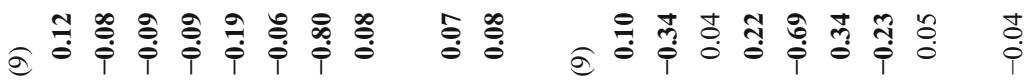
ळ

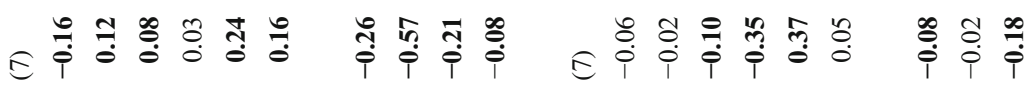
Q

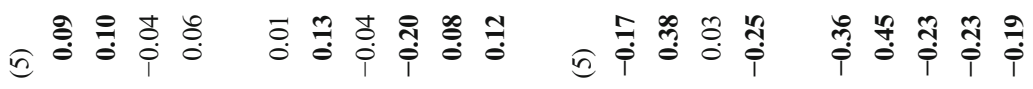

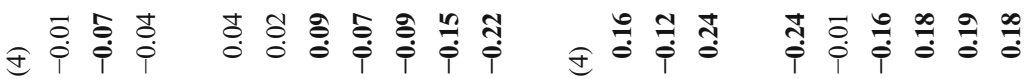

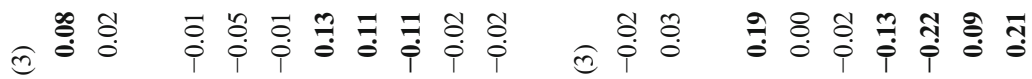

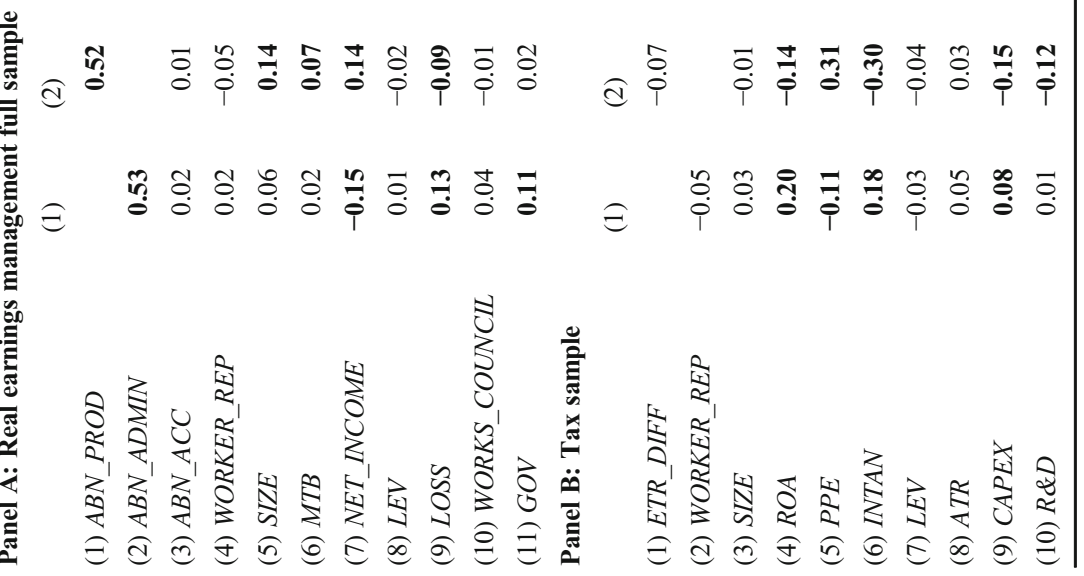




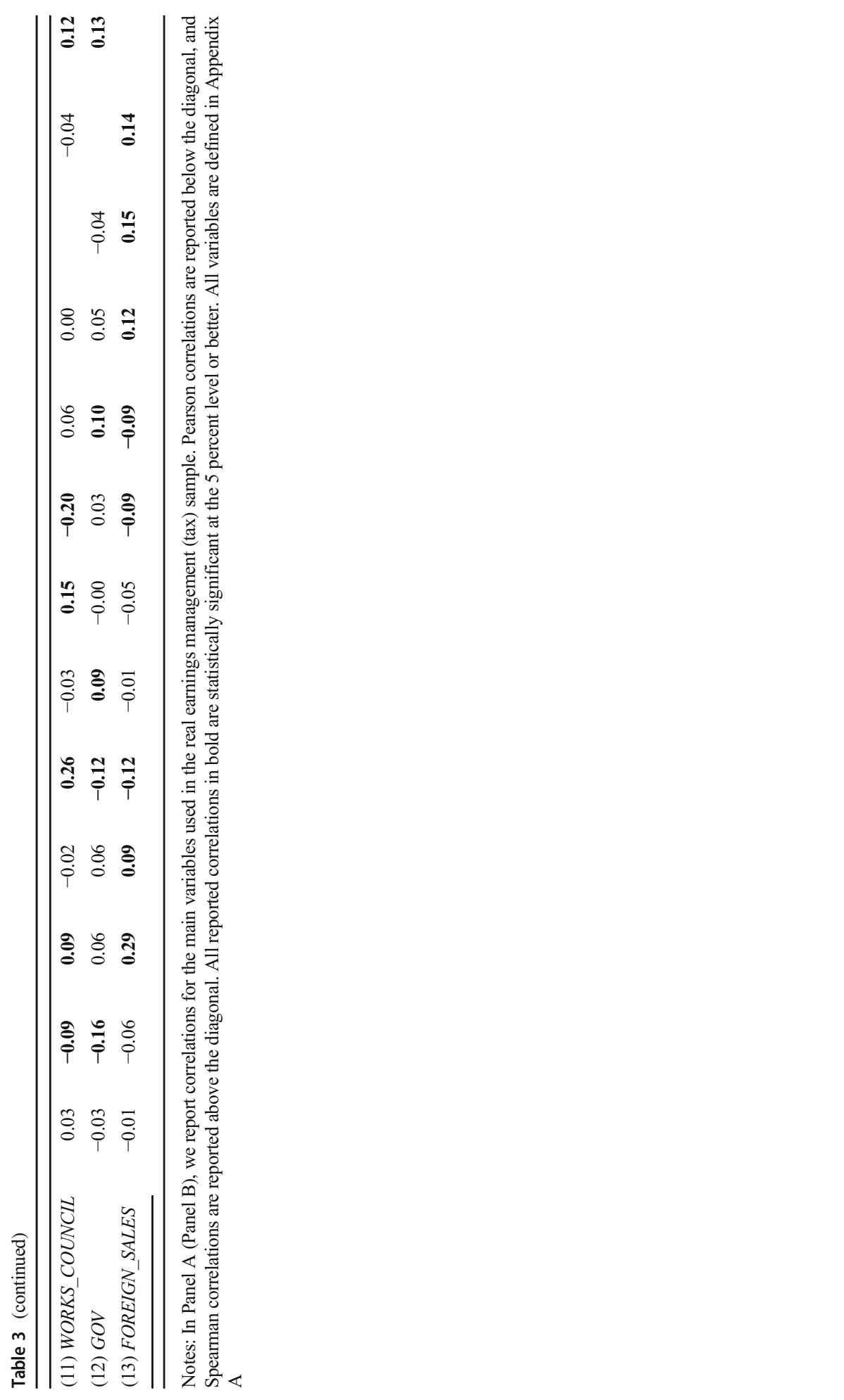


Table 4 reports the OLS estimations, where the conditional mean of the abnormal accruals distribution is not associated with worker representation. Quantile regression shows WORKER_REP is positively associated with $A B N \_A C C$ for firms in the lower tail of the $A B N \_A C C$ distribution and negatively associated with $A B N \_A C C$ for firms in the upper tail of the $A B N \_A C C$ distribution. Consistent with Armstrong et al. (2015),

Table 4 Regression of $A B N$ ACC on WORKER REP and controls $(n=978)$

\begin{tabular}{|c|c|c|c|c|c|c|c|c|c|}
\hline & \multirow[b]{2}{*}{ Pred. } & \multicolumn{2}{|c|}{ WORKER_REP } & \multicolumn{2}{|c|}{ SIZE } & \multicolumn{2}{|c|}{$M T B$} & \multicolumn{2}{|c|}{ NET_INCOME } \\
\hline & & Coef. & $t$-stat & Coef. & $t$-stat & Coef. & $t$-stat & Coef. & $t$-stat \\
\hline OLS & & -0.004 & -0.45 & $-0.006^{* *}$ & -2.14 & 0.000 & 0.01 & $0.068 * * *$ & 3.43 \\
\hline \multicolumn{10}{|c|}{ Quantile } \\
\hline 0.1 & + & $0.041^{*}$ & 1.65 & -0.002 & -0.27 & 0.000 & -0.42 & 0.063 & 1.12 \\
\hline 0.2 & + & $0.017^{*}$ & 1.85 & $-0.005^{*}$ & -1.74 & 0.000 & -0.67 & $0.135 * * *$ & 6.37 \\
\hline 0.3 & + & 0.001 & 0.09 & -0.002 & -0.70 & 0.000 & -0.42 & $0.101 * * *$ & 4.66 \\
\hline 0.4 & & -0.008 & -0.96 & -0.003 & -1.36 & 0.000 & -0.05 & $0.084 * * *$ & 4.51 \\
\hline 0.5 & & -0.010 & -1.39 & -0.002 & -1.02 & 0.000 & 0.42 & $0.050 * * *$ & 3.07 \\
\hline 0.6 & & -0.012 & -1.51 & -0.004 & -1.61 & 0.000 & 0.47 & $0.041 * *$ & 2.31 \\
\hline 0.7 & - & -0.013 & -1.31 & $-0.007 * *$ & -2.49 & 0.000 & 0.60 & $0.049 * *$ & 2.21 \\
\hline 0.8 & - & $-0.025 * *$ & -2.07 & $-0.010^{* * * *}$ & -2.88 & 0.000 & 0.64 & $0.050^{*}$ & 1.86 \\
\hline \multirow[t]{3}{*}{0.9} & - & $-0.051 * * *$ & -2.84 & -0.017 *** & -3.20 & 0.000 & 0.61 & 0.053 & 1.29 \\
\hline & & \multicolumn{2}{|c|}{$L E V$} & \multicolumn{2}{|c|}{ LOSS } & \multicolumn{2}{|c|}{ WORKS_COUNCIL } & \multicolumn{2}{|l|}{$G O V$} \\
\hline & & Coef. & $t$-stat & Coef. & $t$-stat & Coef. & $t$-stat & Coef. & $t$-stat \\
\hline OLS & & $0.075^{* * *}$ & 4.50 & $-0.016^{*}$ & -1.78 & -0.001 & -0.11 & -0.001 & -0.08 \\
\hline \multicolumn{10}{|c|}{ Quantile } \\
\hline 0.1 & & 0.073 & 1.53 & $-0.051^{*}$ & -1.93 & 0.014 & 0.57 & 0.001 & 0.03 \\
\hline 0.2 & & $0.090 * * *$ & 5.05 & -0.008 & -0.84 & $0.019 * *$ & 2.04 & -0.003 & -0.41 \\
\hline 0.3 & & $0.072 * * *$ & 3.97 & -0.014 & -1.38 & 0.014 & 1.46 & -0.004 & -0.54 \\
\hline 0.4 & & $0.080 * * *$ & 5.09 & -0.010 & -1.14 & 0.005 & 0.63 & 0.002 & 0.29 \\
\hline 0.5 & & $0.074 * * *$ & 5.44 & -0.007 & -0.94 & 0.000 & -0.02 & 0.003 & 0.54 \\
\hline 0.6 & & $0.065 * * *$ & 4.36 & -0.009 & -1.09 & -0.002 & -0.30 & 0.003 & 0.45 \\
\hline 0.7 & & $0.071 * * *$ & 3.80 & -0.003 & -0.25 & -0.007 & -0.67 & 0.006 & 0.72 \\
\hline 0.8 & & $0.072 * * *$ & 3.14 & -0.003 & -0.21 & -0.015 & -1.25 & -0.002 & -0.22 \\
\hline 0.9 & & $0.064 *$ & 1.84 & 0.007 & 0.38 & -0.016 & -0.91 & -0.019 & -1.21 \\
\hline
\end{tabular}

Notes: In this table, we report the results of estimating the following equation:

$A B N \_A C C_{i, t}=\beta_{0}+\beta_{1}$ WORKER_REP $P_{i, t}+\beta_{2} S_{I Z E_{i, t}}+\beta_{3}$ MTB $_{i, t}+\beta_{4}$ NET_INCOME $E_{i, t}$ $+\beta_{5} L E V_{i, t}+\beta_{6}$ LOSS $_{i, t}+\beta_{7}$ WORKS_COUNCIL $_{i, t}+\beta_{8} G O V_{i, t}+$ YEAR_FE $+\varepsilon_{i, t}$

We run the equation as OLS and quantile regressions. We report $t$-statistics in the column next to the coefficient estimates. Predicted signs are based on prior literature. *, **, and $* * *$ indicate significance at $10 \%, 5 \%$, and $1 \%$, respectively, in a two-tailed test. Year fixed effects are included in the estimations. The sample covers the period 2009-2015. All observations are subject to the criteria described in Table 1 (Panel A). All variables are defined in Appendix 1. Regression estimation yields an average Pseudo $\mathrm{R}^{2}$ of $3.46 \%$ 
we conclude that this range of variation is ineffectively measured with OLS estimates and that using OLS estimates to generalize corporate governance mechanisms results in misleading inferences. Worker representation is associated with less extreme accrualbased earnings management in both tails of the earnings management distribution, which we attribute to improved board monitoring and reduced agency costs (Claassen 2016; Overland and Samani 2018). ${ }^{32}$ The relations between control variables and $A B N \_A C C$ are generally consistent with prior research. Works councils are not consistently associated with abnormal accruals, mitigating concerns that worker representation proxies for worker participation in governance more generally.

We report our tests of hypothesis 1 in Table 5. When ABN_PROD is the dependent variable, we find that the coefficient on WORKER_REP is significantly positive across all real-earnings management quantiles. Consistent with hypothesis 1 , worker representation is associated with an increase in production levels for firms in the lower tail of the distribution. This increase in production levels is consistent with both effective monitoring and higher payroll and greater job security in the short run. We find no corresponding reduction in abnormal production for firms with high levels of real earnings management. Rather, we continue to observe an increase in production for firms with worker representatives, consistent with an emphasis on payroll maximization. The absence of a reduction in production for firms with high levels of earnings management, together with an increase in production for firms with low levels of earnings management, is evidence that worker representatives are less likely to monitor when real activities manipulation could lead to higher wages and greater job security. Instead, firms with worker representatives are more likely to choose production levels that maximize payroll and job security.

When $A B N \_A D M I N$ is the dependent variable, we find a significantly negative association between $A B N \_A D M I N$ and WORKER_REP for high-level real earnings management firms. Additionally, for firms in the lowest quantiles of the real earnings management distribution, we find no increase in the level of administrative spending cuts, consistent with hypothesis 1 . The absence of an inverse U-shaped relation for $A B N \_P R O D$ and $A B N \_A D M I N$ comports with hypothesis 1 , which proposes that worker representatives maximize payroll when monitoring and payroll maximization are in conflict.

\subsection{Results of tax aggressiveness tests}

Before we test hypothesis 2, we first test the unqualified association between workers on the board and tax aggressiveness. Table 6 shows an inverse Ushaped relation between WORKER_REP and ETR_DIFF. We find significantly positive coefficients in the $0.1,0.2$, and 0.3 quantiles and significantly negative coefficients in the 0.8 and 0.9 quantiles for WORKER_REP. ${ }^{33}$ Workers improve board monitoring that reduces extreme under- and over-aggressive tax planning.

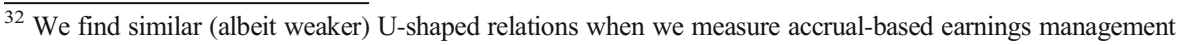
by using the performance-based Jones model (Kothari et al. 2005) or the cash flow Jones model (Kasznik 1999).

${ }^{33}$ The reduction of extreme tax aggressiveness is not limited to the most extreme (0.9) quantile, so we do not believe our results are subject to concerns about whether extremely low ETRs in fact represent tax aggressiveness, as suggested in Schwab et al. (2020).
} 
Table 5 Regression of $A B N \_P R O D(n=235)$ and $A B N \_$ADMIN $(n=978)$ on WORKER_REP and controls

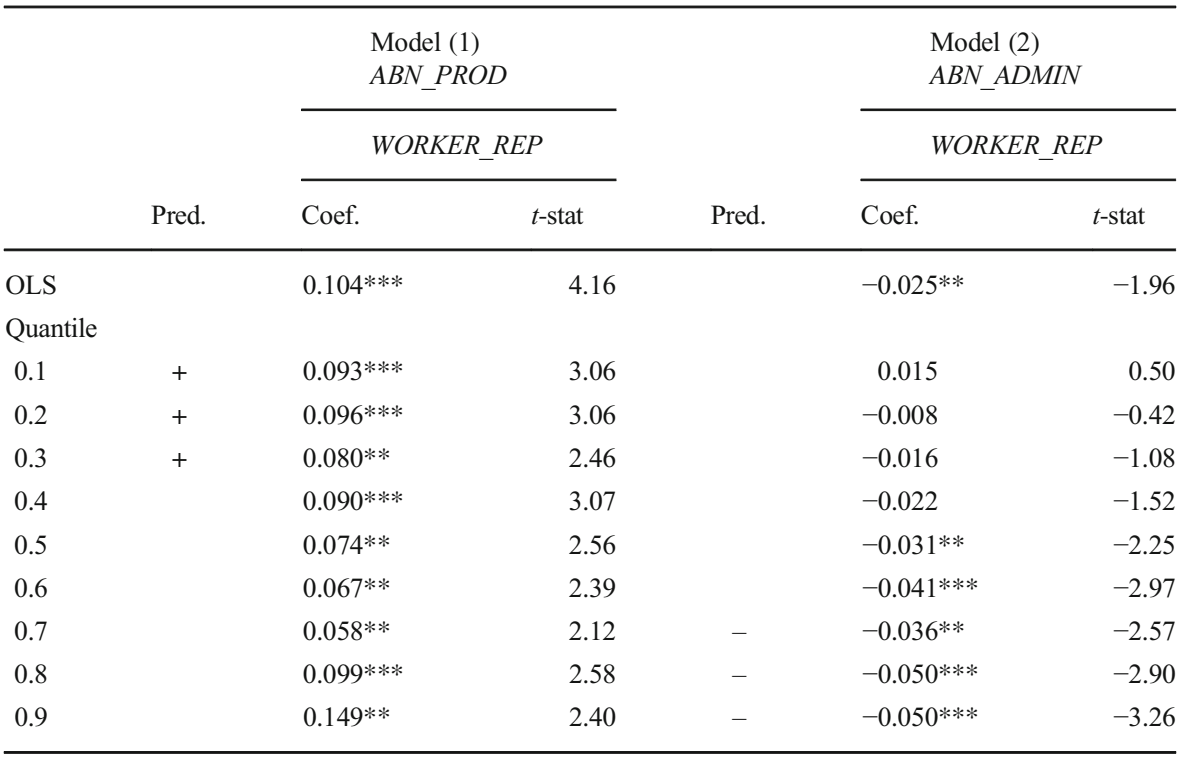

Notes: In this table, we report the results of estimating the following equation:

REM $_{i, t}=\beta_{0}+\beta_{1}$ WORKER_REP $P_{i, t}+\beta_{2}$ SIZE $_{i, t}+\beta_{3}$ MTB $_{i, t}+\beta_{4}$ NET_INCOME $E_{i, t}$ $+\beta_{5} L_{E V} V_{i, t}+\beta_{6}$ LOSS $_{i, t}+\beta_{7}$ WORKS_COUNCIL $_{i, t}+\beta_{8}$ GOV $_{i, t}+$ YEAR_FE $+\varepsilon_{i, t .}$

$R E M_{i, t}$ is either $A B N \_P R O D$ or $A B N \_A D M I N$ (each tested in separate regressions). We run the equation as OLS and quantile regressions. We report $t$-statistics in the column next to the coefficient estimates. Predicted signs are based on hypothesis $1 . *, * *$, and $* * *$ indicate significance at $10 \%, 5 \%$, and $1 \%$, respectively, in a two-tailed test. Estimations of control variables are unreported. Year fixed effects are included in the estimations. The sample covers the period 2009-2015. All observations are subject to the criteria described in Table 1 (Panel A). We restrict the sample to manufacturing firms in Model (1) $(n=235)$. Model (2) includes 978 observations. All variables are defined in Appendix 1. Regression estimation yields an average Pseudo $\mathrm{R}^{2}$ of $10.69 \%$ for Model (1) and an average Pseudo $\mathrm{R}^{2}$ of $4.68 \%$ for Model (2)

This result is consistent with prior research showing that governance mechanisms mitigate agency problems related to under- and over-aggressive tax planning (Armstrong et al. 2015). The relations between the control variables and ETR_DIFF are also generally consistent with prior research.

Table 7 presents the results of testing hypothesis 2 . We continue to observe an inverse U-shaped relation between tax aggressiveness and worker representation when the risk of offshoring is relatively low. Specifically, we find significantly positive coefficients for WORKER_REP_FSALES_LOW in the lower tail of the distribution and significantly negative coefficients in the upper tail of the distribution. Thus, for firms where aggressive tax planning is less likely to conflict with payroll maximization incentives, our results suggest that worker representatives are associated with improved monitoring that reduces extreme under- and over-aggressive tax planning. However, for firms with high levels of foreign sales (WORKER_REP_FSALES_HIGH), we find a significantly negative association between tax aggressiveness and worker representation in the upper tail of the distribution and no corresponding increase in the lower tail of the 
Table 6 Regression of ETR_DIFF on WORKER_REP and controls $(n=670)$

\begin{tabular}{|c|c|c|c|c|c|c|c|c|c|}
\hline & \multirow[b]{2}{*}{ Pred. } & \multicolumn{2}{|c|}{ WORKER_REP } & \multicolumn{2}{|l|}{ SIZE } & \multicolumn{2}{|c|}{$R O A$} & \multicolumn{2}{|l|}{$P P E$} \\
\hline & & Coef. & $t$-stat & Coef. & $t$-stat & Coef. & $t$-stat & Coef. & $t$-stat \\
\hline OLS & & 0.011 & 0.61 & 0.000 & -0.01 & $0.360 * * *$ & 3.92 & -0.001 & -0.02 \\
\hline \multicolumn{10}{|c|}{ Quantile } \\
\hline 0.1 & + & $0.081 * *$ & 2.03 & 0.014 & 1.10 & $0.674 * * *$ & 3.25 & -0.181 & -1.64 \\
\hline 0.2 & + & $0.028 *$ & 1.83 & 0.007 & 1.33 & $0.501 * * *$ & 6.24 & $-0.096 * *$ & -2.26 \\
\hline 0.3 & + & $0.025^{*}$ & 1.68 & 0.007 & 1.44 & $0.347 * * *$ & 4.57 & -0.041 & -1.01 \\
\hline 0.4 & & 0.004 & 0.28 & 0.002 & 0.39 & $0.263 * * *$ & 4.07 & -0.007 & -0.20 \\
\hline 0.5 & & -0.008 & -0.74 & -0.005 & -1.37 & $0.273 * * *$ & 4.88 & 0.024 & 0.80 \\
\hline 0.6 & & -0.017 & -1.33 & $-0.011 * *$ & -2.51 & $0.222 * * *$ & 3.33 & 0.042 & 1.20 \\
\hline 0.7 & - & -0.023 & -1.43 & $-0.015 * * *$ & -2.72 & 0.130 & 1.53 & 0.051 & 1.13 \\
\hline 0.8 & - & $-0.059 * * *$ & -3.23 & $-0.025 * * *$ & -4.16 & 0.049 & 0.52 & $0.110 * *$ & 2.19 \\
\hline \multirow[t]{3}{*}{0.9} & - & $-0.070 * * *$ & -3.61 & $-0.028 * * *$ & -4.31 & -0.070 & -0.69 & $0.125^{* *}$ & 2.33 \\
\hline & & \multicolumn{2}{|c|}{ INTAN } & \multicolumn{2}{|c|}{$L E V$} & \multicolumn{2}{|c|}{$A T R$} & \multicolumn{2}{|c|}{ CAPEX } \\
\hline & & Coef. & $t$-stat & Coef. & $t$-stat & Coef. & $t$-stat & Coef. & $t$-stat \\
\hline$\overline{\mathrm{OLS}}$ & & $0.181 * * *$ & 3.57 & -0.014 & -0.29 & 0.009 & 0.54 & 0.000 & $\overline{0.10}$ \\
\hline \multicolumn{10}{|c|}{ Quantile } \\
\hline 0.1 & & 0.132 & 1.22 & 0.142 & 1.25 & 0.009 & 0.34 & -0.013 & -1.40 \\
\hline 0.2 & & $0.106 * *$ & 2.53 & $0.096^{* *}$ & 2.19 & 0.000 & -0.02 & -0.003 & -0.75 \\
\hline 0.3 & & $0.139 * * *$ & 3.52 & 0.027 & 0.65 & 0.000 & 0.04 & -0.002 & -0.46 \\
\hline 0.4 & & $0.148 * * *$ & 4.37 & -0.028 & -0.78 & 0.005 & 0.62 & $0.006^{* *}$ & 1.96 \\
\hline 0.5 & & $0.173 * * *$ & 5.94 & -0.034 & -1.13 & 0.007 & 1.08 & $0.006 * *$ & 2.29 \\
\hline 0.6 & & $0.175 * * *$ & 5.04 & -0.035 & -0.95 & 0.011 & 1.42 & $0.006^{*}$ & 1.94 \\
\hline 0.7 & & $0.176 * * *$ & 3.98 & -0.008 & -0.17 & 0.015 & 1.49 & 0.005 & 1.33 \\
\hline 0.8 & & $0.134 * * *$ & 2.73 & -0.035 & -0.68 & 0.014 & 1.21 & 0.006 & 1.45 \\
\hline \multirow[t]{3}{*}{0.9} & & 0.062 & 1.18 & 0.034 & 0.62 & 0.008 & 0.66 & $0.008^{*}$ & 1.72 \\
\hline & & \multicolumn{2}{|c|}{$R \& D$} & \multicolumn{2}{|c|}{ WORKS_COUNCIL } & \multicolumn{2}{|c|}{ GOV } & & \\
\hline & & Coef. & $t$-stat & Coef. & $t$-stat & Coef. & $t$-stat & & \\
\hline$\overline{\mathrm{OLS}}$ & & -0.106 & -0.76 & 0.019 & 0.90 & -0.016 & -0.97 & & \\
\hline \multicolumn{10}{|c|}{ Quantile } \\
\hline 0.1 & & 0.001 & 0.00 & 0.044 & 0.94 & -0.008 & -0.23 & & \\
\hline 0.2 & & -0.075 & -0.60 & 0.011 & 0.63 & -0.019 & -1.37 & & \\
\hline 0.3 & & -0.055 & -0.46 & 0.023 & 1.33 & -0.017 & -1.34 & & \\
\hline 0.4 & & -0.062 & -0.62 & $0.025^{*}$ & 1.71 & -0.010 & -0.87 & & \\
\hline 0.5 & & -0.116 & -1.33 & $0.035^{* * *}$ & 2.75 & -0.006 & -0.58 & & \\
\hline 0.6 & & -0.105 & -1.01 & 0.024 & 1.62 & 0.002 & 0.16 & & \\
\hline 0.7 & & -0.052 & -0.39 & 0.015 & 0.81 & 0.007 & 0.45 & & \\
\hline 0.8 & & 0.041 & 0.28 & -0.005 & -0.25 & 0.004 & 0.27 & & \\
\hline 0.9 & & 0.242 & 1.55 & -0.020 & -0.86 & 0.004 & 0.24 & & \\
\hline
\end{tabular}

Notes: In this table, we report the results of estimating the following equation:

ETR_DIFF $_{i, t}=\beta_{0}+\beta_{1}$ WORKER_REP $_{i, t}+\beta_{2}$ SIZE $_{i, t}+\beta_{3}$ ROA $_{i, t}+\beta_{4}$ PPE $_{i, t}+\beta_{5}$ INTAN $_{i, t}$ $+\beta_{6}$ LEV $_{i, t}+\beta_{7} A T R_{i, t}+\beta_{8}$ CAPEX $_{i, t}+\beta_{9} R \& D_{i, t}+\beta_{10}$ WORKS_COUNCIL $_{i, t}+\beta_{11} G_{-}$VV $_{i, t}$

$+Y E A R \_F E+\varepsilon_{i, t}$.

We run the equation as OLS and quantile regressions. We report $t$-statistics in the column next to the coefficient estimates. Predicted signs are based on prior literature. *,**, and $* * *$ indicate significance at $10 \%, 5 \%$, and $1 \%$, respectively, in a twotailed test. Year fixed effects are included in the estimations. The sample covers the period 2009-2015. All observations are subject to the criteria described in Table 1 (PanelB). All variables are defined in Appendix 1. Regression estimation yields an average Pseudo $\mathrm{R}^{2}$ of $8.52 \%$ 
Table 7 Regression of ETR_DIFF on WORKER_REP and controls, partitioned by foreign sales $(n=670)$

\begin{tabular}{|c|c|c|c|c|c|c|}
\hline & \multirow[b]{2}{*}{ Pred. } & \multicolumn{2}{|c|}{ WORKER_REP_FSALES_LOW } & \multirow[b]{2}{*}{ Pred. } & \multicolumn{2}{|c|}{ WORKER_REP_FSALES_HIGH } \\
\hline & & Coef. & $t$-stat & & Coef. & $t$-stat \\
\hline OLS & & 0.031 & 1.36 & & -0.004 & -0.19 \\
\hline \multicolumn{7}{|c|}{ Quantile } \\
\hline 0.1 & + & $0.098 *$ & 1.90 & & 0.054 & 1.17 \\
\hline 0.2 & + & $0.063 * * *$ & 2.99 & & 0.018 & 0.93 \\
\hline 0.3 & + & $0.049 * * *$ & 2.75 & & 0.013 & 0.79 \\
\hline 0.4 & & 0.020 & 1.10 & & -0.002 & -0.14 \\
\hline 0.5 & & 0.004 & 0.24 & & -0.012 & -0.85 \\
\hline 0.6 & & 0.004 & 0.24 & & -0.020 & -1.27 \\
\hline 0.7 & - & -0.008 & -0.40 & - & $-0.037 * *$ & -1.96 \\
\hline 0.8 & - & $-0.049 * *$ & -2.01 & - & $-0.071 * * *$ & -3.27 \\
\hline 0.9 & - & $-0.046^{*}$ & -1.88 & - & $-0.082 * * *$ & -3.73 \\
\hline
\end{tabular}

Notes: In this table, we report the results of estimating the following equation:

ETR_DIFF $_{i, t}=\beta_{0}+\beta_{1}$ WORKER_REP_FSALES_LOW $W_{i, t}+\beta_{2}$ WORKER_REP_FSALES_HIGH $H_{i, t}$

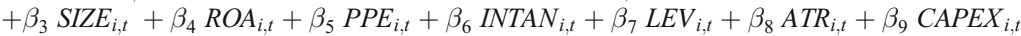
$+\beta_{10} R \& D_{i, t}+\beta_{11}$ WORKS_COUNCIL $L_{i, t}+\beta_{12} G O V_{i, t}+Y E A R \_F E+\varepsilon_{i, t .}$

We run the equation as OLS and quantile regressions. We report $t$-statistics in the column next to the coefficient estimates. Predicted signs are based on hypothesis $2 . *, * *$, and $* * *$ indicate significance at $10 \%, 5 \%$, and $1 \%$, respectively, in a two-tailed test. Estimations of control variables are unreported. Year fixed effects are included in the estimations. The sample covers the period 2009-2015. All observations are subject to the criteria described in Table 1 (Panel B). All variables are defined in Appendix 1. Regression estimation yields an average Pseudo $\mathrm{R}^{2}$ of $8.81 \%$

distribution. Consistent with hypothesis 2, workers block aggressive tax strategies when the risk of offshoring jobs is higher. This result is consistent with the notion that worker representatives on corporate boards maximize payroll for workers when tax transactions impact payroll and job security. ${ }^{34}$

As an additional test, we provide evidence on how workers consider the benefits and costs of tax avoidance. Tax avoidance can be an important source of internal financing in response to financial constraints (Law and Mills 2015; Edwards et al. 2016). Financial constraints also increase the risk of layoffs because constrained firms may cut labor costs to meet financial obligations (Ofek 1993; Agrawal and Matsa 2013). When firms are financially constrained, workers may permit more tax-aggressive actions to reduce the risk of insolvency. In Table 8, we partition our sample into

\footnotetext{
${ }^{34}$ Firms with worker representation report significantly higher cash ETRs and higher average industry-size adjusted CASH ETRS (measured as average cash ETR of firms from the same industry and from the same quintile of total assets, less a firm's cash ETR, which is calculated as cash paid for taxes scaled by pretax income) than firms without worker representation. One reason for this difference is higher pension and other post-employment benefit commitments, which lead to higher accrued expense and deferred tax assets but do not lower current cash-taxes paid. Consistent with the univariate difference, we find a negative and significant association between worker representation and cash tax aggressiveness in all quantiles except the lowest $(0.1$, 0.2 , and 0.3 ). The difference in cash taxes paid is consistent with payroll maximization incentives around pensions and other post-employment benefits.
} 
Table 8 Regression of ETR_DIFF on WORKER_REP and controls, partitioned by foreign sales for subsamples of financially constrained and unconstrained firms

Panel A: Subsample of financially constrained firms $(n=335)$

\begin{tabular}{|c|c|c|c|c|}
\hline & \multicolumn{2}{|c|}{ WORKER_REP_FSALES_LOW } & \multicolumn{2}{|c|}{ WORKER_REP_FSALES_HIGH } \\
\hline & Coef. & $t$-stat & Coef. & $t$-stat \\
\hline OLS & 0.029 & 0.70 & 0.032 & 0.94 \\
\hline \multicolumn{5}{|c|}{ Quantile } \\
\hline 0.1 & -0.002 & -0.02 & 0.061 & 0.64 \\
\hline 0.2 & $0.064 *$ & 1.71 & 0.043 & 1.27 \\
\hline 0.3 & $0.061 *$ & 1.93 & 0.046 & 1.51 \\
\hline 0.4 & $0.058^{*}$ & 1.76 & 0.028 & 1.00 \\
\hline 0.5 & 0.035 & 1.16 & 0.006 & 0.24 \\
\hline 0.6 & 0.014 & 0.49 & -0.006 & -0.23 \\
\hline 0.7 & -0.024 & -0.83 & -0.030 & -1.22 \\
\hline 0.8 & -0.038 & -0.97 & -0.037 & -1.10 \\
\hline 0.9 & 0.005 & 0.10 & -0.010 & -0.25 \\
\hline
\end{tabular}

Panel B: Subsample of financially unconstrained firms $(\boldsymbol{n}=\mathbf{3 3 5})$

\begin{tabular}{|c|c|c|c|c|}
\hline & WORK & $S \_L O W$ & WORKER & $H I G H$ \\
\hline & Coef. & $t$-stat & Coef. & $t$-stat \\
\hline OLS & 0.035 & 1.41 & -0.024 & -0.97 \\
\hline Quan & & & & \\
\hline 0.1 & 0.098 & 1.30 & 0.064 & 0.89 \\
\hline 0.2 & 0.037 & 1.04 & -0.005 & -0.16 \\
\hline 0.3 & 0.031 & 1.55 & -0.005 & -0.26 \\
\hline 0.4 & 0.008 & 0.36 & -0.019 & -0.87 \\
\hline 0.5 & -0.004 & -0.20 & -0.020 & -0.99 \\
\hline 0.6 & 0.001 & 0.06 & -0.030 & -1.29 \\
\hline 0.7 & -0.025 & -0.99 & $-0.056^{* *}$ & -2.33 \\
\hline 0.8 & -0.011 & -0.45 & $-0.081 * * *$ & -3.61 \\
\hline 0.9 & -0.025 & -0.67 & $-0.122 * * *$ & -3.37 \\
\hline
\end{tabular}

Notes: In this table, we report the results of estimating the following equation:

ETR_DIFF ${ }_{i, t}=\beta_{0}+\beta_{1}$ WORKER_REP_FSALES_LOW ${ }_{i, t}+\beta_{2}$ WORKER_REP_FSALES_HIGH ${ }_{i, t}$ $+\beta_{3} S_{I Z E_{i, t}}+\beta_{4} R O A_{i, t}+\beta_{5} P P E_{i, t}+\beta_{6} I N T A N_{i, t}+\beta_{7} L E V_{i, t}+\beta_{8} A T R_{i, t}+\beta_{9} C A P E X_{i, t}$ $+\beta_{10} R \& D_{i, t}+\beta_{11}$ WORKS_COUNCIL $L_{i, t}+\beta_{12} G O V_{i, t}+Y E A R \_F E+\varepsilon_{i, t}$.

We differentiate between financially constrained (Panel A) and unconstrained (Panel B) firms using Altman's (1968) Z-score (median-split). We run the equation as OLS and quantile regressions. We report $t$-statistics in the column next to the coefficient estimates. *, **, and $* * *$ indicate significance at $10 \%, 5 \%$, and $1 \%$, respectively, in a two-tailed test. Estimations of control variables are unreported. Year fixed effects are included in the estimations. The sample covers the period 2009-2015. All observations are subject to the criteria described in Table 1 (Panel B). All variables are defined in Appendix 1. Panel A regression estimation yields an average Pseudo $\mathrm{R}^{2}$ of $11.05 \%$, whereas Panel B regression estimation yields an average Pseudo $\mathrm{R}^{2}$ of $13.78 \%$ 
financially constrained and unconstrained firms using Altman's (1968) Z-score (median-split). We find that when firms are financially constrained and the risk of offshoring is relatively low (Panel A), WORKER_REP_FSALES_LOW is associated with a significant increase in tax aggressiveness for less aggressive firms; we find that there is no reduction in tax aggressiveness for highly aggressive firms. However, when the offshoring risk is relatively high in financially constrained firms, we observe insignificant coefficients on WORKER_REP_FSALES_HIGH in all quantiles. Workers do not facilitate additional tax planning when the risk of offshoring is high, even though their firms are financially constrained. However, workers also permit tax aggressiveness at the upper end of the distribution. In contrast, we find that worker representatives block aggressive tax strategies when a financially unconstrained firm (i.e., low insolvency risk) has a relatively high offshoring risk (Panel B). These findings are consistent with worker representatives balancing the competing risks of job loss due to offshoring and insolvency. They are also consistent with long-run payroll maximization. ${ }^{35}$

Together, our evidence indicates that payroll incentives dominate monitoring incentives when the two are in conflict. We conclude that worker representation can help to reduce agency issues in general. However, when workers are required to monitor transactions that impact payroll and job security, they appear to prioritize their own concerns.

\subsection{Robustness tests}

We conduct several robustness tests. First, we address the endogeneity issue that is typical in many areas of empirical corporate governance research (e.g., Hermalin and Weisbach 1998; Hermalin and Weisbach 2003; Adams et al. 2010). The German corporate governance setting reduces concerns related to reverse causality because worker representation is not a firm choice, as it is legally mandated and universal across firms. ${ }^{36}$ Our research design exploits the discontinuity around the legal threshold of 500 domestic workers to reduce the influence of differences in firm characteristics of firms with and without worker representation. We assume that firms around this threshold do not strategically manipulate their number of domestic workers. However, employment levels are at least partially a firm choice and are influenced by management decisions. Managers could intentionally reduce the number of domestic workers to avoid worker representation when employment levels reach the threshold of 500 domestic workers, although this is unlikely to occur in practice. Kim et al. (2018) and Lin et al. (2018) show that in Germany, operational considerations, not avoidance of worker representation, determine employment decisions.

\footnotetext{
${ }^{35}$ We also investigate differences between financially constrained and unconstrained firms in the real earnings management setting. Our results (Table 5) hold for financially unconstrained firms, whereas the coefficient on WORKER_REP is insignificant in nearly all quantiles in financially constrained firms. These findings indicate that worker representatives do not promote production increases or block administrative expenditure cuts when the risk of job losses (in financially constrained firms) is relatively high.

${ }^{36}$ Our real earnings management sample contains only two firms that move from no worker representation to worker representation, and the tax sample only includes one such firm. Therefore, we cannot investigate firms that cross thresholds. For an examination of firms crossing thresholds and abnormal announcement returns, see Petry (2018).
} 
Table 9 Placebo tests at a false threshold of 1,000 domestic workers

\section{Panel A: Regression of $A B N \_P R O D$ and $A B N \_A D M I N$ on PLACEBO}

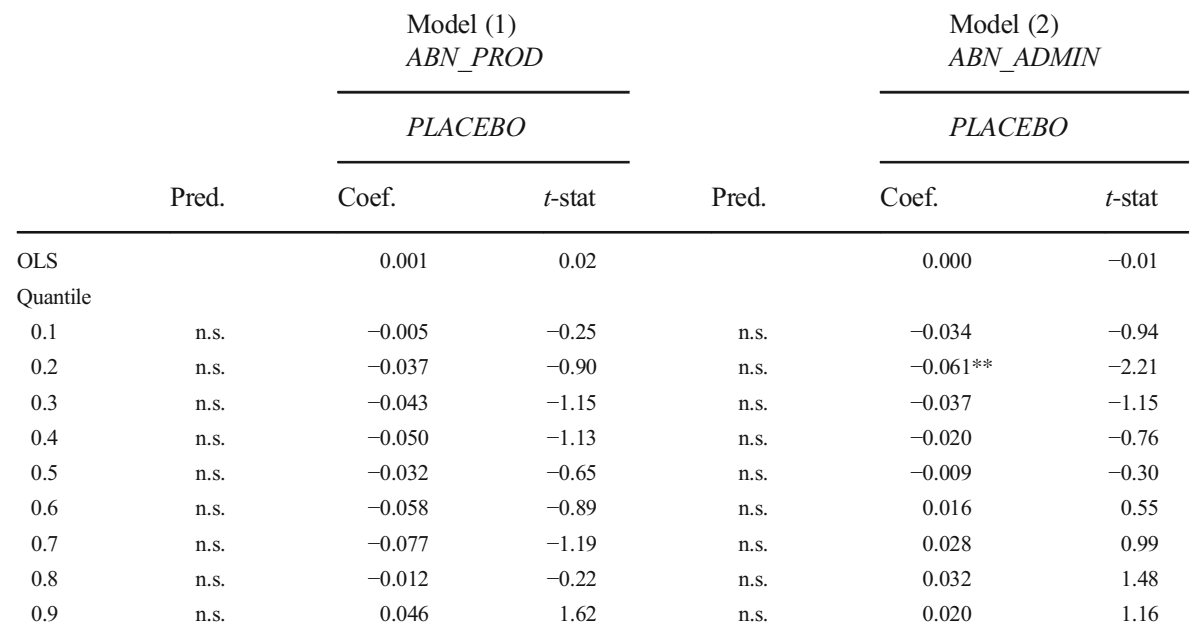

Panel B: Regression of ETR_DIFF on PLACEBO partitioned by foreign sales

\begin{tabular}{|c|c|c|c|c|c|c|}
\hline & \multirow[b]{2}{*}{ Pred. } & \multicolumn{2}{|c|}{$\begin{array}{l}\text { PLACEBO } \\
\text { FSALES_LOW }\end{array}$} & \multirow[b]{2}{*}{ Pred. } & \multicolumn{2}{|c|}{$\begin{array}{l}\text { PLACEBO } \\
\text { FSALES_HIGH }\end{array}$} \\
\hline & & Coef. & $t$-stat & & Coef. & $t$-stat \\
\hline OLS & & 0.005 & 0.25 & & -0.026 & -0.90 \\
\hline \multicolumn{7}{|c|}{ Quantile } \\
\hline 0.1 & n.s. & 0.011 & 0.12 & n.s. & -0.100 & -0.98 \\
\hline 0.2 & n.s. & 0.028 & 1.29 & n.s. & $-0.052 * *$ & -2.12 \\
\hline 0.3 & n.s. & 0.024 & 1.43 & n.s. & -0.020 & -1.05 \\
\hline 0.4 & n.s. & 0.018 & 1.07 & n.s. & -0.009 & -0.50 \\
\hline 0.5 & n.s. & 0.013 & 0.74 & n.s. & -0.004 & -0.22 \\
\hline 0.6 & n.s. & -0.001 & -0.05 & n.s. & -0.009 & -0.46 \\
\hline 0.7 & n.s. & -0.022 & -0.96 & n.s. & -0.030 & -1.16 \\
\hline 0.8 & n.s. & -0.017 & -0.66 & n.s. & 0.003 & 0.12 \\
\hline 0.9 & n.s. & -0.021 & -0.68 & n.s. & 0.013 & 0.36 \\
\hline
\end{tabular}

Notes: In Panel A, we report the results of estimating the following equation:

REM $_{i, t}=\beta_{0}+\beta_{1}$ PLACEBO $_{i, t}+\beta_{2}$ SIZE $_{i, t}+\beta_{3}$ MTB $_{i, t}+\beta_{4}$ NET_INCOME $i, t+\beta 5$ LEV $_{i, t}$ $+\beta_{6}$ LOSS $_{i, t}+\beta_{7}$ WORKS_COUNCIL $_{i, t}+\beta_{8} G O V_{i, t}+$ YEAR_FE $+\varepsilon_{i, t}$.

$R E M_{i, t}$ is either $A B N_{-} P R O D$ or $A B N \_A D M I N$ (each tested in separate regressions). In Panel B, we report the results of estimating the following equation:

ETR_DIFF ${ }_{i, t}=\beta_{0}+\beta_{1}$ PLACEBO_FSALES_LOW ${ }_{i, t}+\beta_{2}$ PLACEBO_FSALES_HIGH $H_{i, t}+\beta_{3}$ SIZE $_{i, t}$ $+\beta_{4} R O A_{i, t}+\beta_{5} P P E_{i, t}+\beta_{6} I N T A N_{i, t}+\beta_{7} L E V_{i, t}+\beta_{8} A_{T R}+\beta_{9} C A P E X_{i, t}+\beta_{10} R \& D_{i, t}+\beta_{11}$ WORKS_COUNCIL $L_{i, t}+\beta_{12} G O V_{i, t}+Y E A R \_F E+\varepsilon_{i, t}$.

We run both equations as OLS and quantile regressions. We expect insignificant (n.s.) coefficients on whether a firm is above the pseudo threshold (PLACEBO). We report $t$-statistics in the column next to the coefficient estimates. $* * *$, and $* * *$ indicate significance at $10 \%, 5 \%$, and $1 \%$, respectively, in a two-tailed test. Estimations of control variables are unreported. Year fixed effects are included in the estimations. The sample covers the period 2009-2015. In these tests, the sample contains all firm-years with domestic workers between 500 and 1,500. All variables are defined in Appendix 1. Panel A regression estimation yields an average Pseudo $\mathrm{R}^{2}$ of $32.97 \%$ (Model 1) and $8.41 \%$ (Model 2). Panel B regression estimation yields an average Pseudo $\mathrm{R}^{2}$ of $9.01 \%$ 
To alleviate concerns that our results are driven by size effects or any other structural effect around the threshold of 500 domestic workers, we conduct placebo tests at hypothetical thresholds of 600-1,400 domestic workers and limit the sample to firm-years with \pm 500 domestic workers around each pseudo-threshold. We would expect to find similar results at this hypothetical threshold if firm size and not worker representation drives our results. We report the result of the placebo test at the 1,000-domestic worker threshold in Table 9. PLACEBO is an indicator variable that is equal to one if the firm reports more than 1,000 domestic workers and zero otherwise. Panel A presents the results for the real earnings management sample and shows that $P L A C E B O$ is not associated with $A B N \_P R O D$. In addition, $P L A C E B O$ is not significantly negatively associated with $A B N \_A D M I N$ for high-level real earnings management firms. We also find no inverse-U shaped relation between PLACEBO and $A B N \_A C C$ in an untabulated test. Panel $\mathrm{B}$ presents the result of our placebo test for the tax aggressiveness sample. We partition PLACEBO by foreign sales, similar to our main tests in Table 7. We do not observe an inverse U-shaped relation between PLACEBO_FSALES_LOW and ETR_DIFF. For firms with high levels of foreign sales and domestic workers above the false threshold of 1,000, we do not observe a significantly negative association between PLACEBO_FSALES_HIGH and $E T R \_D I F F$ in the upper tail of the distribution. We also fail to find an inverse U-shaped relation between PLACEBO and ETR_DIFF (untabulated). For alternative pseudo-thresholds beginning at 600 domestic workers and increasing in increments of 100 up to 1,400 , we observe primarily insignificant associations between PLACEBO and our variables of interest. The absence of a consistent pattern of significance around pseudo-thresholds increases our confidence that our findings are unique at the threshold of 500 domestic workers and are due to the inclusion of worker representatives on corporate boards. Still, we acknowledge that our discontinuity design and robustness tests do not completely rule out the endogeneity issue. Therefore, as with every association study, readers should interpret our results with caution.

In the second set of robustness tests, we use foreign subsidiaries and foreign jobs, both hand-collected from publicly available annual reports, as alternative proxies for the likelihood that a firm moves operations offshore. In Table 10, Panel A, we re-estimate Eq. (2), substituting whether the firm has subsidiaries in countries that are typically used for offshoring above or below the median. ${ }^{37}$ In Panel B, we measure whether the proportion of foreign jobs relative to total jobs is above or below the median. Table 10 indicates that our inferences are robust to using foreign subsidiaries and foreign jobs instead of foreign sales to measure the likelihood of moving firm operations offshore. ${ }^{38}$ Consistent with our main

\footnotetext{
${ }^{37}$ We use the database of the Organisation for Economic Co-operation and Development (OECD), OECD.Stat, which discloses the number of people employed in German multinational firms by country location, to define countries that are typically used for offshoring (i.e., the ratio of the number of people employed in foreign subsidiaries per country to the total number of people employed in foreign subsidiaries). 38 Additionally, we investigate whether the tax haven usage differs between firms with and without worker representatives. Based on the tax haven definition used in Dyreng and Lindsey (2009), we do not find that the likelihood of subsidiaries domiciled in tax havens differs between these two firm types. This finding is in line with our expectation that worker representatives block tax strategies that could imply the shifting of personnel, but not strategies that could imply the shifting of income (as is common in most tax havens).
} 
Table 10 Regression of ETR_DIFF on WORKER_REP and controls, partitioned by foreign subsidiaries or foreign jobs

Panel A: WORKER_REP partitioned by foreign subsidiaries $(n=670)$

\begin{tabular}{|c|c|c|c|c|c|c|}
\hline & \multirow[b]{2}{*}{ Pred. } & \multicolumn{2}{|c|}{ WORKER_REP_FSUBS_LOW } & \multirow[b]{2}{*}{ Pred. } & \multicolumn{2}{|c|}{ WORKER_REP_FSUBS_HIGI } \\
\hline & & Coef. & $t$-stat & & Coef. & $t$-stat \\
\hline OLS & & 0.016 & 0.68 & & 0.007 & 0.35 \\
\hline \multicolumn{7}{|c|}{ Quantile } \\
\hline 0.1 & + & $0.116^{* *}$ & 2.29 & & 0.061 & 1.37 \\
\hline 0.2 & + & $0.065 * * *$ & 2.97 & & 0.014 & 0.71 \\
\hline 0.3 & + & $0.034 *$ & 1.72 & & 0.010 & 0.59 \\
\hline 0.4 & & 0.012 & 0.73 & & 0.000 & -0.03 \\
\hline 0.5 & & -0.008 & -0.52 & & -0.008 & -0.61 \\
\hline 0.6 & & -0.020 & -1.16 & & -0.007 & -0.46 \\
\hline 0.7 & - & -0.023 & -1.05 & - & -0.026 & -1.32 \\
\hline 0.8 & - & $-0.071 * * *$ & -2.93 & - & $-0.050^{* *}$ & -2.33 \\
\hline 0.9 & - & $-0.057^{* *}$ & -2.31 & - & $-0.086^{* * *}$ & -3.94 \\
\hline
\end{tabular}

Panel B: WORKER_REP partitioned by foreign jobs $(n=667)$

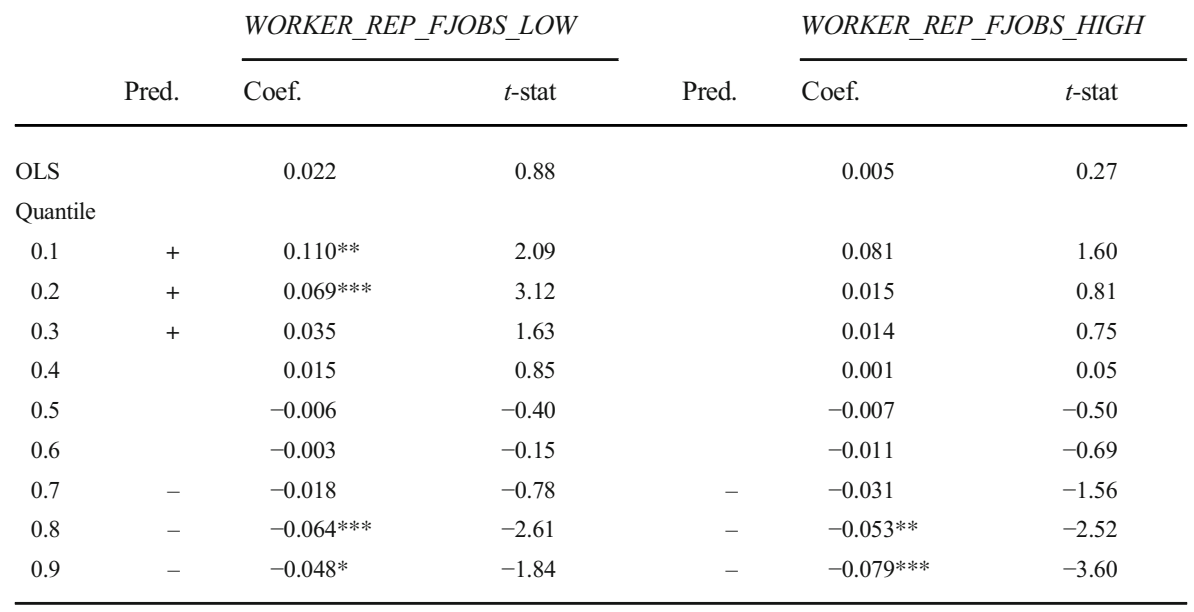

Notes: In Panel A, we report the results of estimating the following equation:

ETR_DIFF $F_{i, t}=\beta_{0}+\beta_{1}$ WORKER_REP_FSUBS_LOW $W_{i, t}+\beta_{2}$ WORKER_REP_FSUBS_HIGH $H_{i, t}$

$+\beta_{3} S_{I Z E_{i, t}}+\beta_{4} R O A_{i, t}+\beta_{5} P P E_{i, t}+\beta_{6} I_{N T A N_{i, t}}+\beta_{7} L E V_{i, t}+\beta_{8} A_{T R}+\beta_{9}$ CAPEX $_{i, t}$

$+\beta_{10} R \& D_{i, t}+\beta_{11}$ WORKS_COUNCIL $L_{i, t}+\beta_{12} G O V_{i, t}+$ YEAR_FE $+\varepsilon_{i, t}$.

In Panel $\mathrm{B}$, we report the results of estimating the following equation:

ETR_DIFF $F_{i, t}=\beta_{0}+\beta_{1}$ WORKER_REP_FJOBS_LOW $W_{i, t}+\beta_{2}$ WORKER_REP_FJOBS_HIGH $H_{i, t}$

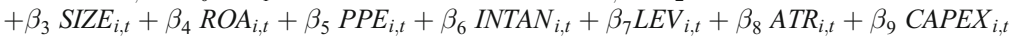

$+\beta_{10} R \& D_{i, t}+\beta_{11}$ WORKS_COUNCIL $L_{i, t}+\beta_{12} G O V_{i, t}+Y E A R \_F E+\varepsilon_{i, t}$.

We run both equations as OLS and quantile regressions. We report $t$-statistics in the column next to the coefficient estimates. Predicted signs are based on hypothesis $2 . * * *$, and $* * *$ indicate significance at $10 \%, 5 \%$, and $1 \%$, respectively, in a two-tailed test. Estimations of control variables are unreported. Year fixed effects are included in the estimations. The sample covers the period 2009-2015. All observations are subject to the criteria described in Table 1 (Panel B). All variables are defined in Appendix 1. Panel A regression estimation yields an average Pseudo $\mathrm{R}^{2}$ of $8.71 \%$, whereas Panel B regression estimation yields an average Pseudo $\mathrm{R}^{2}$ of $8.76 \%$ 
results, we find an inverse U-shaped relation between both offshoring specifications and $E T R \_D I F F$. For firms with high levels of foreign subsidiaries (i.e., WORKER_REP_FSUBS_HIGH) and foreign jobs (i.e., WORKER_REP_FJOBS_HIGH) we find a significantly negative association in the upper tail of the distribution. Overall, our results confirm that worker representatives are effective monitors. However, when payroll maximization incentives conflict with monitoring duties, workers prioritize payroll maximization incentives.

In the third set of robustness tests (untabulated), we consider industry-level measures to measure the likelihood of offshoring. First, we identify the industries that have been most affected by offshoring in Germany. Approximately $88 \%$ of all offshored German jobs are related to consumer discretionary, industrials, and materials industries (derived from OECD.Stat). Accordingly, the offshoring risk in these industries is higher than in all other industries. In line with our main findings, we find that worker representatives block aggressive tax strategies when the offshoring risk in their industry is high. Second, we use the R\&D intensity (i.e., R\&D expenses divided by total assets) and capital intensity (i.e., depreciation and amortization expense divided by total number of employees) to consider whether it is more difficult to offshore highly skilled jobs or jobs in industries that are very capital intensive. We find that worker representatives block aggressive tax strategies when the risk of offshoring jobs is higher (i.e., the fraction of highly skilled jobs or the capital intensity is relatively low). In sum, our results are robust to using industry-level measures instead of foreign activity (i.e., foreign sales, subsidiaries, or jobs) measures.

The remaining robustness tests examine whether our inferences are sensitive to design choices. We test whether our real earnings management results are influenced by estimation errors resulting from two-step estimation models (Chen et al. 2018). Chen et al. (2018) demonstrate that using residuals as dependent variables can generate biased coefficients and standard errors that can lead to incorrect inferences. To avoid estimation errors from two-step estimation models, they recommend using all model regressors in a single-step regression. We use raw values of our real earnings management variables as dependent variables (i.e., $P R O D$ and $A D M I N)$ and include all control variables in a single-step regression model; WORKER_REP remains our variable of interest. We also add industry-year indicator variables and their interactions with each of the first-step regressors, because our two-step procedure requires estimation by industry and year. In (untabulated) regressions, we find that our results are robust to using a single-step regression model and that our inferences are unlikely to be influenced by estimation errors in two-step regression models. We also consider alternative quantile breakpoints. Our inferences are unchanged when we use quartiles.

\section{Conclusion}

This paper provides new evidence on the governance role of workers by identifying two settings where workers' payroll maximization incentives are likely to conflict with the monitoring duties of board members. Our objective is to examine under what conditions worker representation on the board improves monitoring.

Using quantile regressions, we find strong evidence that workers on boards are generally associated with decreased agency costs and improved monitoring. However, for a subset of transactions that are directly connected to workers' incentives 
and for which their payroll maximization incentives conflict with their monitoring duties, we find that worker representatives prioritize payroll maximization.

We recognize that inferences regarding the role of boards in a corporate governance system should be transferred to other countries with caution. Although corporate governance systems and board compositions depend on regulations in each country, we believe that our results are relevant to the U.S. setting because one-tier boards are more similar to two-tier boards than the rules would suggest. One- and two-tier board systems converge due to an increased number of independent directors on one-tier boards and enhanced cooperation between supervisory and management boards on two-tier boards (Hopt 1997), but we acknowledge that differences across countries may limit generalizability.

Overall, this study contributes to the literature on boards and corporate decisionmaking by providing evidence on the monitoring and payroll maximization roles of worker representatives. Our results suggest that worker representatives do prioritize maximizing payroll. While this prioritization reduces their influence as monitors, it is consistent with calls by the Business Roundtable for corporations to consider objectives other than maximizing shareholder value (the Washington Post 2019).

\section{Appendix 1}

Table 11 Variable definitions

\begin{tabular}{ll}
\hline Variable Name & Definition \\
\hline$A B N \_P R O D$ & Abnormal production costs measured as residuals from industry-year \\
& (two-digit GICS code) regressions, following Roychowdhury (2006). \\
& Where $P R O D=$ cost of goods sold (COGS) + change in inventory \\
& $($ INVT) $) ; A=$ Total Assets; $S=$ Sales: \\
& $P R O D_{t} / A_{t-1}=\beta_{0}+\beta_{1}\left(1 / A_{t-1}\right)+\beta_{2}\left(S_{t} / A_{t-1}\right)+\beta_{3}\left(\Delta S_{t} / A_{t-1}\right)+\beta_{4}\left(\Delta S_{t-1} / A_{t-1}\right)+\varepsilon_{t}$.
\end{tabular}

$A B N \_A D M I N$

$A B N \_A C C$

ETR_DIFF

WORKER_REP

WORKER_REP_FSALES_LOW

WORKER_REP_FSALES_HIGH Indicator variable equal to one if a firm's board includes worker

WORKER_REP_FSUBS_LOW representatives and if this firm reports foreign sales to total sales (SALE) above the median, zero otherwise.

Discretionary administrative expenses (XSGA) measured as negative one times the residuals from industry-year regressions following Roychowdhury (2006):

$A D M I N_{t} / A_{t-1}=\beta_{0}+\beta_{1}\left(1 / A_{t-1}\right)+\beta_{2}\left(S_{t-1} / A_{t-1}\right)+\varepsilon_{t .}$.

Abnormal level of accrual-based earnings management (discretionary accruals), measured by using the original Jones model (Jones 1991).

Average GAAP ETR of firms from the same industry (two-digit GICS codes) and from the same quintile of total assets less a firm's GAAP ETR. GAAP ETR is computed as a firm's total income tax expense (TXT) divided by pre-tax income (PI).

Indicator variable equal to one if a firm's board includes worker representatives, zero otherwise.

Indicator variable equal to one if a firm's board includes worker representatives and if this firm reports foreign sales to total sales (SALE) below the median, zero otherwise.

Indicator variable equal to one if a firm's board includes worker representatives and if this firm has a below-the-median offshoring-risk, zero otherwise. The country-level offshoring risk ratio is defined as the ratio of the number of people employed in that country by subsidiaries 
Table 11 (continued)

Variable Name Definition

of German firms relative to the total number employees in all foreign subsidiaries of German firms (data derived from OECD.Stat). Country ratios are then multiplied by the number of a firm's subsidiaries in the respective country and aggregated to a firm's overall offshoring-risk across all countries (subsidiary data are hand-collected from publicly available annual reports).

WORKER_REP_FSUBS_HIGH Indicator variable equal to one if a firm's board includes worker representatives and if this firm has above-the-median offshoring-risk ratio, zero otherwise. See the calculation of offshoring risk above.

WORKER_REP_FJOBS_LOW Indicator variable equal to one if a firm's board includes worker representatives and if this firm reports foreign jobs to total jobs below the median, zero otherwise.

WORKER_REP_FJOBS_HIGH Indicator variable equal to one if a firm's board includes worker representatives and if this firm reports foreign jobs to total jobs above the median, zero otherwise.

PLACEBO

PLACEBO_FSALES_LOW

PLACEBO_FSALES_HIGH

SIZE

Indicator variable equal to one if a firm has more than 1,000 domestic workers, zero otherwise.

Indicator variable equal to one if a firm has more than 1,000 domestic workers and if this firm reports foreign sales to total sales (SALE) below the median, zero otherwise.

Indicator variable equal to one if a firm has more than 1,000 domestic workers and if this firm reports foreign sales to total sales (SALE) above the median, zero otherwise.

Logarithm of a firm's lagged market value (i.e., year-end share price (PRC) multiplied by the number of shares outstanding (SHROUT)).

$M T B$

The ratio of lagged market value of equity to lagged book value of equity (CEQ).

NET_INCOME

Net income (NICON) scaled by lagged total assets (AT).

LEV

Ratio of long-term debt (DLTT) plus current debt (DLC) to total assets (AT).

LOSS

Indicator variable equal to one if a firm's pre-tax income (PI) is negative, zero otherwise.

WORKS_COUNCIL

Indicator variable equal to one if the proportion of firms in the industry with a works council is above the median of all industries, zero otherwise. Information on works council coverage by industry is obtained from the German Institute of Employment Research of the Federal Employment Agency (Dribbusch and Birke 2019, p. 14).

GOV

Following the methodology used by DeFond et al. (2005), GOV is equal to one if the sum of indicator variables for board size, audit committee size, and number of board meetings is greater than the sample median, and zero otherwise. The indicator variable for board size is equal to one if a firm's board size is less than or equal to the sample median, and zero otherwise. The indicator variables for audit committee size and number of board meetings are each equal to one if the size of the audit committee (relative to the overall board size) or the frequency of board meetings is greater than the sample median, and zero otherwise. Board size, audit committee size, and number of board meetings are hand-collected from annual reports for each year in the sample. 
Table 11 (continued)

\begin{tabular}{ll}
\hline Variable Name & Definition \\
\hline INTAN & Level of intangible assets (INTAN) scaled by total assets (AT). \\
ATR & Total sales (SALE) divided by total assets (AT). \\
CAPEX & Amount spent on capital assets (CAPX) scaled by net property, plant, and \\
& equipment (PPENT). \\
R\&D & Ratio of R\&D expenses (XRD) scaled by total assets (AT). Missing R\&D \\
& data are coded as 0. \\
FOREIGN_SALES & The ratio of foreign sales to total sales (SALE). \\
\hline
\end{tabular}

Notes: Compustat data item abbreviations are written in all caps and bold font (COMPUSTAT)

Acknowledgements We thank one anonymous referee, Jennifer Blouin (editor), Andrew Belnap, Mary Billings, Larry Fauver, Bradford Hepfer, Yun Ke (discussant), Lillian Mills, Aaron Nelson, Michelle Nessa, George Plesko (discussant), Stephen Salter (discussant), Steven Savoy, Jeff Wilks, Ryan Wilson, and Ben Yost (discussant), as well as participants at the 2018 National Tax Association's Annual Conference on Taxation, the 2019 American Taxation Association Midyear Meeting, the 2019 CAAA Annual Conference, the 2019 BYU Accounting Research Symposium, the 2020 Joint Midyear Meeting of the AIS, SET and International Sections, the 2020 AAA Annual Meeting, and the 2020 Review of Accounting Studies Conference for valuable comments and suggestions. This paper received the Public Interest - Best Paper Award for the 2020 International Section Midyear meeting. An earlier version of this paper was circulated under the title, "What Happens to Tax Aggressiveness and Earnings Management When Workers Enter the Boardroom?"

Funding Open Access funding enabled and organized by Projekt DEAL.

Data availability Data are available from the sources cited in the text.

Open Access This article is licensed under a Creative Commons Attribution 4.0 International License, which permits use, sharing, adaptation, distribution and reproduction in any medium or format, as long as you give appropriate credit to the original author(s) and the source, provide a link to the Creative Commons licence, and indicate if changes were made. The images or other third party material in this article are included in the article's Creative Commons licence, unless indicated otherwise in a credit line to the material. If material is not included in the article's Creative Commons licence and your intended use is not permitted by statutory regulation or exceeds the permitted use, you will need to obtain permission directly from the copyright holder. To view a copy of this licence, visit http://creativecommons.org/licenses/by/4.0/.

\section{References}

Adams, R.B., and D. Ferreira. 2007. A theory of friendly boards. Journal of Finance 62 (1): 217-250.

Adams, R.B., B.E. Hermalin, and M.S. Weisbach. 2010. The role of boards of directors in corporate governance: A conceptual framework and survey. Journal of Economic Literature 48 (1): 58-107.

Agrawal, A.K., and D.A. Matsa. 2013. Labor unemployment risk and corporate financing decisions. Journal of Financial Economics 108: 449-470.

Ahern, K.R., and A.K. Dittmar. 2012. The changing of the boards: The impact on firm valuation of mandated female board representation. The Quarterly Journal of Economics 127 (1): 137-197.

Alchian, A.A. 1984. Specificity, specialization, and coalitions. Journal of Institutional and Theoretical Economics 140 (1): $34-49$.

Alchian, A.A., and H. Demsetz. 1972. Production, information costs, and economic organization. The American Economic Review 62 (5): 777-795.

Altman, E.I. 1968. Financial ratios, discriminant analysis and the prediction of corporate bankruptcy. Journal of Finance 23 (4): 589-609. 
Armstrong, C.S., J.L. Blouin, A.D. Jagolinzer, and D.F. Larcker. 2015. Corporate governance, incentives, and tax avoidance. Journal of Accounting and Economics 60: 1-17.

Badertscher, B.A., S.P. Katz, S.O. Rego, and R.J. Wilson. 2019. Conforming tax avoidance and capital market pressure. The Accounting Review 94 (6): 1-30.

Balakrishnan, K., J.L. Blouin, and W.R. Guay. 2019. Tax aggressiveness and corporate transparency. The Accounting Review 94 (1): 45-69.

Ball, R., and L. Shivakumar. 2008. Earnings quality at initial public offerings. Journal of Accounting and Economics 45: 324-349.

Balsmeier, B., A. Bermig, and A. Dilger. 2013. Corporate governance and employee power in the boardroom: An applied game theoretic analysis. Journal of Economic Behavior \& Organization 91: 51-74.

Barton, J., \& Simko, P.J. (2002). The balance sheet as an earnings management constraint. The Accounting Review, 77(s-1), 1-27.

Bassett, G., and H.-L. Chen. 2001. Portfolio style: Return-based attribution using quantile regression. Empirical Economics 26: 293-305.

Beissinger, T., N. Chusseau, and J. Hellier. 2016. Offshoring and labour market reforms in Germany: Assessment and policy implications. Economic Modelling 53: 314-333.

Bloomberg. (2018a). Why German corporate boards include workers. A brief history of "co-determination," which Elizabeth Warren now wants to bring to U.S. corporations. Available at: https://www.bloomberg. com/view/articles/2018-08-24/why-german-corporate-boards-include-workers-for-co-determination.

Bloomberg. (2018b). Why U.S. corporate boards don't include workers. The (strangely brief) history of employee representation in American boardrooms. Available at: https:/www.bloomberg.com/opinion/ articles/2018-08-27/why-u-s-corporate-boards-don-t-include-workers.

Blouin, J.L. 2014. Defining and measuring tax planning aggressiveness. National Tax Journal 67 (4): 875900.

Buchinsky, M. 1994. Changes in the U.S. wage structure 1963-1987: Application of quantile regression. Econometrica 62 (2): 405-458.

Buchinsky, M. 1998. The dynamics of changes in the female wage distribution in the USA: A quantile regression approach. Journal of Applied Econometrics 13 (1): 1-30.

Budryk, Z. (2019). Walmart shareholders reject Sanders-backed proposal to put workers on board. The hill. Available at: https://thehill.com/policy/finance/447175-walmart-shareholders-reject-proposal-sandersadvocated-to-put-workers-on-board.

Burgstahler, D.C., L. Hail, and C. Leuz. 2006. The importance of reporting incentives: Earnings management in European private and public firms. The Accounting Review 81 (5): 983-1016.

Byrd, D.T., and M.S. Mizruchi. 2005. Bankers on the board and the debt ratio of firms. Journal of Corporate Finance 11: 129-173.

Chen, S., X. Chen, Q. Cheng, and T. Shevlin. 2010. Are family firms more tax aggressive than non-family firms? Journal of Financial Economics 95: 41-61.

Chen, W., P. Hribar, and S. Melessa. 2018. Incorrect inferences when using residuals as dependent variables. Journal of Accounting Research 56 (3): 751-796.

Chen, X., Q. Cheng, and X. Wang. 2015. Does increased board independence reduce earnings management? Evidence from recent regulatory reforms. Review of Accounting Studies 20: 899-933.

Cheng, Q., J. Lee, and T. Shevlin. 2016. Internal governance and real earnings management. The Accounting Review 91 (4): 1051-1085.

Chyz, J.A., and F.B. Gaertner. 2018. Can paying "too much" or "too little" tax contribute to forced CEO turnover? The Accounting Review 93 (1): 103-130.

Chyz, J.A., W.S.C. Leung, O.Z. Li, and O.M. Rui. 2013. Labor unions and tax aggressiveness. Journal of Financial Economics 108: 675-698.

Claassen, D. (2016). Supervisory board compensation structure, employee representation, and earnings management: Evidence from German boards. Working Paper, Ludwig-Maximilians-Universität München.

Cloyd, C.B., Mills, L.F., \& Weaver, C.D. (2003). Firm valuation effects of the expatriation of U.S. corporations to taxhaven countries. The Journal of the American Taxation Association, 25(supplement), 87-109.

Cohen, D.A., and P. Zarowin. 2010. Accrual-based and real earnings management activities around seasoned equity offerings. Journal of Accounting and Economics 50: 2-19.

Cohen, D.A., A. Dey, and T.Z. Lys. 2008. Real and accrual-based earnings management in the pre- and postSarbanes-Oxley period. The Accounting Review 83 (3): 757-787.

Cohen, L.J., M.M. Cornett, A.J. Marcus, and H. Tehranian. 2014. Bank earnings management and tail risk during the financial crisis. Journal of Money, Credit and Banking 46 (1): 171-197.

Collins, J., D. Kemsley, and M. Lang. 1998. Cross-jurisdictional income shifting and earnings valuation. Journal of Accounting Research 36 (2): 209-229. 
Dahya, J., and J.J. McConnell. 2007. Board composition, corporate performance, and the Cadbury committee recommendation. Journal of Financial and Quantitative Analysis 42 (3): 535-564.

Daske, H., G. Gebhardt, and S. McLeay. 2006. The distribution of earnings relative to targets in the European Union. Accounting and Business Research 36 (3): 137-167.

De Waegenaere, A., R. Sansing, and J.L. Wielhouwer. 2015. Financial accounting measures of tax reporting aggressiveness: Contracting and measurement. Contemporary Accounting Research 32 (1): 223-242.

DeFond, M.L., R.N. Hann, and X. Hu. 2005. Does the market value financial expertise on audit committees of boards of directors? Journal of Accounting Research 43 (2): 153-193.

Desai, M.A., A. Dyck, and L. Zingales. 2007. Theft and taxes. Journal of Financial Economics 84: 591-623.

Deutsche Bundesbank. 2018. The impact of the internationalization of German firms on domestic investment. Deutsche Bundesbank Monthly Report January 2018: 13-26.

DIHK. (2018). DIHK-Umfrage - Auslandsinvestitionen in der Industrie 2018. Available at: https://www.dihk. de/resource/blob/3374/5e4ded8edbedff07df90b3bf957aa5a9/auslandsinvestitionen-2018-data.pdf

Dittmann, I., E. Maug, and C. Schneider. 2010. Bankers on the boards of German firms: What they do, what they are worth, and why they are (still) there. Review of Finance 14: 35-71.

Dribbusch, H., \& Birke, P. (2019). Trade unions in Germany. Challenges in a time of transition. Available at: http:/library.fes.de/pdf-files/id/ipa/15399.pdf.

Drinhausen, F., and H.-M. Eckstein. 2018. Beck'sches Handbuch der AG. Gesellschaftsrecht, Steuerrecht, Börsengang. 3rd ed. C.H. Beck.

Dyreng, S.D., and B.P. Lindsey. 2009. Using financial accounting data to examine the effect of foreign operations located in tax havens and other countries on U.S. multinational firms' tax rates. Journal of Accounting Research 47 (5): 1283-1316.

Dyreng, S.D., and K.S. Markle. 2016. The effect of financial constraints on tax-motivated income shifting by U.S. multinationals. The Accounting Review 91 (6): 1601-1627.

Dyreng, S.D., M. Hanlon, and E.L. Maydew. 2008. Long-run corporate tax avoidance. The Accounting Review 83 (1): 61-82.

Edwards, A., C. Schwab, and T. Shevlin. 2016. Financial constraints and cash tax savings. The Accounting Review 91 (3): 859-881.

Edwards, C.H., Lang, M.H., Maydew, E.L., \& Shackelford, D.A. (2004). Germany’s repeal of the corporate capital gains tax: The equity market response. The Journal of the American Taxation Association, 26(supplement), 73-97.

Eide, E., and M.H. Showalter. 1998. The effect of school quality on student performance: A quantile regression approach. Economics Letters 58: 345-350.

ETUI. (2018). European Trade Union Institute Policy Brief No. 11/2018 European Economic, Employment and Social Policy, The EU company law package: How it should be improved to strengthen workers' rights and avoid abuse through cross-border company mobility. Available at: https://www.etui.org/ Publications2/Policy-Briefs/European-Economic-Employment-and-Social-Policy/The-EU-company-lawpackage-how-it-should-be-improved-to-strengthen-workers-rights-and-avoid-abuse-through-crossborder-company-mobility.

European Parliament. (2017). The impact of schemes revealed by the Panama papers on the economy and finances of a sample of member states. Available at: http:/www.europarl.europa.eu/thinktank/de/ document.html?reference=IPOL STU\%282017\%29572717.

Faleye, O., R. Hoitash, and U. Hoitash. 2011. The costs of intense board monitoring. Journal of Financial Economics 101: 160-181.

Fan, Q. 2007. Earnings management and ownership retention for initial public offering firms: Theory and evidence. The Accounting Review 82 (1): 27-64.

Fauver, L., and M.E. Fuerst. 2006. Does good corporate governance include employee representation? Evidence from German corporate boards. Journal of Financial Economics 82: 673-710.

Feng, Z.-Y., \& Huang, H.-W. (2020). Corporate governance and earnings management: A quantile regression approach. International Journal of Finance \& Economics, 1-17.

Financial Times. (2016). Theresa May should beware of imitating the German model. Available at: https:// www.ft.com/content/56f1513c-4813-11e6-8d68-72e9211e86ab.

FitzRoy, F.R., and K. Kraft. 1993. Economic effects of codetermination. The Scandinavian Journal of Economics 95 (3): 365-375.

FitzRoy, F.R., and K. Kraft. 2005. Co-determination, efficiency and productivity. British Journal of Industrial Relations 43 (2): 233-247.

Frank, M.M., L.J. Lynch, and S.O. Rego. 2009. Tax reporting aggressiveness and its relation to aggressive financial reporting. The Accounting Review 84 (2): 467-496. 
Freeman, R.B., and E.P. Lazear. 1995. An economic analysis of works councils. In Works councils: Consultation, representation and co-operation in industrial relations, ed. J. Rogers and W. Streeck, 27-52. Chicago University Press.

Furubotn, E.G. 1988. Codetermination and the modern theory of the firm: A property rights analysis. The Journal of Business 61 (2): 165-181.

Furubotn, E.G., and S.N. Wiggins. 1984. Plant closings, worker reallocation costs and efficiency gains to labor representation on boards of directors. Journal of Institutional and Theoretical Economics 140 (1): 176-192.

Ge, W., and J.-B. Kim. 2014. Boards, takeover protection, and real earnings management. Review of Quantitative Finance and Accounting 43: 651-682.

German Trade Union Confederation. (2019). Der Konzernjahresabschluss. Bewertungsansätze kennen und Verrechnungssysteme beherrschen. Available at: https://www.dgb-bildungswerk.de/seminar/18128821.

Glaum, M., K. Lichtblau, and J. Lindemann. 2004. The extent of earnings management in the U.S. and Germany. Journal of International Accounting Research 3 (2): 45-77.

Goldbach, S., Nagengast, A.J., Steinmüller, E., \& Wamser, G. (2017). The effect of investing abroad on investment at home: On the role of technology, tax savings, and internal capital markets. Deutsche Bundesbank discussion paper no 14/2017.

Gorton, G., and F.A. Schmid. 2000. Universal banking and the performance of German firms. Journal of Financial Economics 58: 29-80.

Gorton, G., and F.A. Schmid. 2004. Capital, labor, and the firm: A study of German codetermination. Journal of the European Economic Association 2 (5): 863-905.

Graham, J.R., M. Hanlon, and T. Shevlin. 2011. Real effects of accounting rules: Evidence from multinational firms' investment location and profit repatriation decisions. Journal of Accounting Research 49 (1): 137-185.

Greiner, A., M.J. Kohlbeck, and T.J. Smith. 2017. The relationship between aggressive real earnings management and current and future audit fees. Auditing: A Journal of Practice \& Theory 36 (1): 85-107.

Guenther, D.A., S.R. Matsunaga, and B.M. Williams. 2017. Is tax avoidance related to firm risk? The Accounting Review 92 (1): 115-136.

Gunny, K.A. 2010. The relation between earnings management using real activities manipulation and future performance: Evidence from meeting earnings benchmarks. Contemporary Accounting Research 27 (3): 855888.

Gupta, S., and K. Newberry. 1997. Determinants of the variability in corporate effective tax rates: Evidence from longitudinal data. Journal of Accounting and Public Policy 16 (1): 1-34.

Hammer, T.H., S.C. Currall, and R.N. Stern. 1991. Worker representation on boards of directors: A study of competing roles. Industrial and Labor Relations Review 44 (4): 661-680.

Hanlon, M., R. Lester, and R. Verdi. 2015. The effect of repatriation tax costs on U.S. multinational investment. Journal of Financial Economics 116: 179-196.

Hans Boeckler Foundation. (2004). Zur aktuellen Kritik der Mitbestimmung im Aufsichtsrat. Available at: https:// www.boeckler.de/pdf/mitbestimmung_2004.pdf.

Hans Boeckler Foundation. (2008). Arbeitnehmerbank deckelt Bezüge. Available at: https://www.boeckler.de/ 22045 22049.htm.

Hans Boeckler Foundation. (2019). Jahresabschluss: Wie analysiere ich ihn kritisch? Schritte zur eigenständigen Analyse und Klärung komplexer Bilanzierungsfragen. Available at: https:/www.mitbestimmung.de/html/ jahresabschluss-wie-analysiere-ich-ihn-8873.html.

Hermalin, B.E., and M.S. Weisbach. 1998. Endogenously chosen boards of directors and their monitoring of the CEO. The American Economic Review 88 (1): 96-118.

Hermalin, B.E., and M.S. Weisbach. 2003. Boards of directors as an endogenously determined institution: A survey of the economic literature. Federal Reserve Bank of New York Economic Policy Review 9: 7-26.

Hillman, A.J., G. Nicholson, and C. Shropshire. 2008. Directors' multiple identities, identification, and board monitoring and resource provision. Organization Science 19 (3): 441-456.

Hockett, R., Basu, K., Alpert, D., Taub, J., Frank, R., Omarova, S., Mukunda, G., Kaboub, F., Rahman, K.S., Tcherneva, P.R., Lubben, S.J., Herndon, T., Madrick, J., \& Lazonick, W. (2018). Warren introduces accountable capitalism act. Letter of support from academics and investors. Available at: https://www.warren.senate.gov/ download/federal-corporate-charter-letter-of-support.

Hopt, K.J. 1997. The German two-tier board (Aufsichtsrat): A German view on corporate governance. In Comparative corporate governance: Essays and materials, ed. K.J. Hopt and E. Wymeersch, 3-20. Walter de Gruyter.

Hribar, P., and D.C. Nichols. 2007. The use of unsigned earnings quality measures in tests of earnings management. Journal of Accounting Research 45 (5): 1017-1053.

Huizinga, H., and L. Laeven. 2008. International profit shifting within multinationals: A multi-country perspective. Journal Public Economics 92: 1164-1182. 
Jacob, J. 1996. Taxes and transfer pricing: Income shifting and the volume of intrafirm transfers. Journal of Accounting Research 34 (2): 301-312.

Jensen, M.C., and W.H. Meckling. 1979. Rights and production functions: An application to labor managed firms and codetermination. The Journal of Business 52 (4): 469-506.

Jones, J.J. 1991. Earnings management during import relief investigations. Journal of Accounting Research 29 (2): 193-228.

Jungmann, C. 2006. The effectiveness of corporate governance in one-tier and two-tier board system. European Company and Financial Law Review 3: 426-474.

Kasznik, R. 1999. On the association between voluntary disclosure and earnings management. Journal of Accounting Research 37 (1): 57-81.

Kim, E.H., E. Maug, and C. Schneider. 2018. Labor representation in governance as an insurance mechanism. Review of Finance 22 (4): 1251-1289.

Klassen, K.J., and S.K. Laplante. 2012. Are U.S. multinational corporations becoming more aggressive income shifters? Journal of Accounting Research 50 (5): 1245-1285.

Klein, A. 2002. Audit committee, board of director characteristics, and earnings management. Journal of Accounting and Economics 33: 375-400.

Koenker, R., and G. Bassett. 1978. Regression quantiles. Econometrica 46 (1): 33-50.

Koenker, R., and K.F. Hallock. 2001. Quantile regression. Journal of Economic Perspective 15 (4): 143-156.

Kothari, S.P., A.J. Leone, and C.E. Wasley. 2005. Performance matched discretionary accrual measures. Journal of Accounting and Economics 39: 163-197.

Krieg, G. (2019). Bernie Sanders confronts Walmart leaders at annual shareholders meeting. CNN politics. Available at: https://edition.cnn.com/2019/06/05/politics/bernie-sanders-walmart-meeting/index.html.

Kroszner, R.S., and P.E. Strahan. 2001. Bankers on boards: Monitoring, conflicts of interest, and lender liability. Journal of Financial Economics 62: 415-452.

Law, K.K.F., and L.F. Mills. 2015. Taxes and financial constraints: Evidence from linguistic cues. Journal of Accounting Research 53 (4): 777-819.

Law, K.K.F., and L.F. Mills. 2017. Military experience and corporate tax avoidance. Review of Accounting Studies 22: 141-184.

Lee, Y., Ng, S., Shevlin, T., \& Venkat, A. (2020). The reputation costs of tax avoidance: Evidence from Glassdoor. com ratings. The Accounting Review, forthooming.

Lin, C., Schmid, T., \& Sun, Y. (2019). Conflict or collusion? How employees in the boardroom affect executive compensation. Working paper, University of Hong Kong, and Brandeis International business school.

Lin, C., T. Schmid, and Y. Xuan. 2018. Employee representation and financial leverage. Journal of Financial Economics 127: 303-324.

Linck, J.S., J.M. Netter, and T. Yang. 2008. The determinants of board structure. Journal of Financial Economics 87: 308-328.

Linck, J.S., J.M. Netter, and T. Yang. 2009. The effects and unintended consequences of the Sarbanes-Oxley act on the supply and demand for directors. The Review of Financial Studies 22: 3287-3328.

Lisowsky, P. 2010. Seeking shelter: Empirically modeling tax shelters using financial statement information. The Accounting Review 85 (5): 1693-1720.

May, T. (2016). We can make Britain a country that works for everyone. Speech in Birmingham launching her national campaign to become leader of the Conservative Party and prime minister of the United Kingdom, July 11, 2016. Available at: http://www.ukpol.co.uk/theresa-may-2016-speech-to-launch-leadership-campaign/.

McGaughey, E. 2016. The codetermination bargains: The history of German corporate and labor law. Columbia Journal of European Law 23: 135-176.

Mills, L.F., M.M. Erickson, and E.L. Maydew. 1998. Investments in tax planning. Journal of the American Taxation Association 20 (1): 1-20.

Minnick, K., and T. Noga. 2010. Do corporate governance characteristics influence tax management? Journal of Corporate Finance 16: 703-718.

Mosteller, F., \& Tukey, J.W. (1977). Data analysis and regression. A second course in statistics. Mass.: AddisonWesley.

Mueller-Jentsch, W. 1995. Auf dem Prüfstand: Das deutsche Modell der industriellen Beziehungen. The German Journal of Industrial Relations 2 (1): 11-24.

Ofek, E. 1993. Capital structure and firm response to poor performance: An empirical analysis. Journal of Financial Economics 34: 3-30.

Oler, M., T. Shevlin, and R. Wilson. 2007. Examining investor expectations concerning tax savings on the repatriations of foreign earnings under the American jobs creation act of 2004. The Journal of the American Taxation Association 29 (2): 25-55. 
Overland, C., \& Samani, N. (2018). The sheep watching the shepherd: Employee representation on the board and earnings quality. Working Paper, University of Goethenburg.

Petry, S. 2018. Mandatory worker representation on the board and its effect on shareholder wealth. Financial Management 47: 25-54.

PricewaterhouseCoopers. (2009). Der Prüfungsausschuss. Best Practices einer effizienten Überwachung. $3^{\text {rd }}$ edition.

Rego, S.O. 2003. Tax-avoidance activities of U.S. multinational corporations. Contemporary Accounting Research 20 (4): 805-833.

Rego, S.O., and R. Wilson. 2012. Equity risk incentives and corporate tax aggressiveness. Journal of Accounting Research 50 (3): 775-810.

Reuters. (2019). RPT-INSIGHT-Turmoil at Thyssenkrupp marks battle for Germany's economic identity. Available at: https:/www.reuters.com/article/thyssenkrupp-restructuring/rpt-insight-turmoil-atthyssenkrupp-marks-battle-for-germanys-economic-identity-idUSL5N22W35U.

Roychowdhury, S. 2006. Earnings management through real activities manipulation. Journal of Accounting and Economics 42: 335-370.

Schrader, K., \& Laaser, C.-F. (2009). Globalisierung in der Wirtschaftskrise: Wie sicher sind die Jobs in Deutschland? Kiel Institute for the World Economy (IfW), No. 465.

Schwab, C.M., Stomberg, B., \& Xia, J. (2020). How well do effective tax rates capture tax avoidance? Working Paper, Indiana University.

Srinidhi, B., F.A. Gul, and J. Tsui. 2011. Female directors and earnings quality. Contemporary Accounting Research 28 (5): 1610-1644.

The Guardian. (2016). The Guardian view on workers' representation: May's U-turn is a betrayal, Editorial. Available at: https://www.theguardian.com/commentisfree/2016/nov/21/guardian-view-workersrepresentation-theresa-may-betrayal.

The New York Times. (2019). Workers on corporate boards? Germany's had them for decades. Available at: https://www.nytimes.com/2019/01/06/opinion/warren-workers-boards.html.

The New York Times. (2020). Biden's economic team suggests focus on workers and income equality. Available at: https://www.nytimes.com/2020/11/30/business/biden-economics-yellen-labor.html.

The Wall Street Journal. (2018). Companies shouldn't be accountable only to shareholders. Available at: https://www.wsj.com/articles/companies-shouldnt-be-accountable-only-to-shareholders-1534287687.

The Wall Street Journal. (2019). Germany's labor system would be difficult to import to U.S. Available at: https://www.wsj.com/articles/germanys-labor-system-would-be-difficult-to-import-to-u-s-11571580002.

The Washington Post. (2019). Group of top CEOs says maximizing shareholder profits no longer can be the primary goal of corporations. Available at: https:/www.washingtonpost.com/business/2019/08/19/ lobbying-group-powerful-ceos-is-rethinking-how-it-defines-corporations-purpose/.

Visvanathan, G. 2008. Corporate governance and real earnings management. Academy of Accounting and Financial Studies Journal 12 (1): 9-22.

Walmart 8-K filed June 10, (2019). Available at: https://stock.walmart.com/investors/financial-information/ sec-filings/.

Warren, E. (2018). Warren introduces accountable capitalism act. Comprehensive legislation to eliminate skewed market incentives and return to the era when American corporations and American workers did well together. Available at: https://www.warren.senate.gov/newsroom/press-releases/warren-introducesaccountable-capitalism-act.

Weber, A. 2009. An empirical analysis of the 2000 corporate tax reform in Germany: Effects on ownership and control in listed companies. International Review of Law and Economics 29: 57-66.

Williams, B.M. 2018. Multinational tax incentives and offshored U.S. jobs. The Accounting Review 93 (5): $293-324$.

Wilson, R.J. 2009. An examination of corporation tax shelter participants. The Accounting Review 84 (3): 969-999.

Xie, B., W.N. Davidson, and P.J. DaDalt. 2003. Earnings management and corporate governance: The role of the board and the audit committee. Journal of Corporate Finance 9: 295-316.

Zang, A.Y. 2012. Evidence on the trade-off between real activities manipulation and accrual-based earnings management. The Accounting Review 87 (2): 675-703.

Zhao, Y., K.H. Chen, Y. Zhang, and M. Davis. 2012. Takeover protection and managerial myopia: Evidence from real earnings management. Journal of Accounting and Public Policy 31: 109-135.

Publisher's note Springer Nature remains neutral with regard to jurisdictional claims in published maps and institutional affiliations. 


\section{Affiliations}

\section{Cristi A. Gleason ${ }^{1} \cdot$ Sascha Kieback ${ }^{2} \cdot$ Martin Thomsen $^{2} \cdot$ Christoph Watrin $^{2}$}

Cristi A. Gleason

cristi-gleason@uiowa.edu

Sascha Kieback

sascha.kieback@wiwi.uni-muenster.de

Christoph Watrin

christoph.watrin@wiwi.uni-muenster.de

1 The University of Iowa, Iowa City, IA, USA

2 University of Muenster, Muenster, Germany 